\title{
Synthesis and potential antimicrobial activity of novel a-aminophosphonates derivatives bearing substituted quinoline or quinolone and thiazole moieties
}

\author{
Bilal Litim $\mathbb{D}^{1} \cdot$ Abdelghani Djahoudi $^{2} \cdot$ Saida Meliani ${ }^{3} \cdot$ Abbes Boukhari $^{1}$ \\ Received: 28 July 2021 / Accepted: 17 October 2021 / Published online: 2 November 2021 \\ (c) The Author(s), under exclusive licence to Springer Science+Business Media, LLC, part of Springer Nature 2021
}

\begin{abstract}
To develop novel antimicrobial agents, and based on the biologically active heterocyclic quinoline and thiazole substituted, a series of novel $\alpha$-aminophosphonates $(\mathbf{9 a}-\mathbf{h})$ and $(\mathbf{1 0 i}-\mathbf{l})$ derivatives that incorporated quinoline or quinolone, and coumarylthiazole or 5-phenylthiazol-2-amine moieties were designed and synthesized via Kabachnik-Fields reaction in the presence of ionic liquid under ultrasound irradiation. All the new compounds were obtained in good yield with a simple workup and were confirmed using various spectroscopic methods. The in vitro antimicrobial activity of all synthesized compounds were screened in terms of MIC values against the selected strains of Gram-negative and Gram-positive bacteria and two fungal strains using the broth micro-dilution method. The results showed that most of the tested compounds showed moderate inhibitory activities against both Gram-positive and -negative bacteria compared with reference drugs. The following compounds $9 \mathrm{e}, 9 \mathrm{~g}, 9 \mathrm{~h}, 9 \mathbf{i}$ and $9 \mathrm{f}, 9 \mathrm{~g}, 9 \mathbf{h}, 10 \mathrm{k}, 10 \mathrm{l}$ are the most active against Gram-positive and Gram-negative bacteria strains, respectively, with MIC values ranging between 0.25 and $128 \mu \mathrm{g} / \mathrm{mL}$. The synthesized compounds $9 \mathbf{9 b}, \mathbf{9 c}, \mathbf{9 f}$, 9g, 9h, 10k, and 10l exhibited excellent antifungal inhibition with MIC values ranging between 0.25 and $32 \mu \mathrm{g} / \mathrm{mL}$. Structure-activity relationship revealed that the presence of coumarylthiazole moiety and hydroxyl in the quinoline group increased the inhibitory activity against microbial strains pathogens. These results confirm that the synthesized compounds can be potential antimicrobial drugs candidate.
\end{abstract}

Supplementary information The online version contains supplementary material available at https://doi.org/10.1007/s00044021-02815-5.

Bilal Litim

billellitim23@gmail.com

1 Laboratory of Organic Synthesis, Modeling and Optimization of Chemical Processes, Department of Chemistry, Faculty of Sciences, Badji Mokhtar-Annaba University, BP 12, 23000 Annaba, Algeria
2 Laboratory of Microbiology, Department of Pharmacy, Faculty of Medicine, Badji Mokhtar-Annaba University, BP 205 Annaba, Algeria

Laboratory of Microbiology, Department of Biochemistry, Faculty of Sciences, Badji Mokhtar-Annaba University, BP 205 Annaba, Algeria 


\section{Graphical Abstract}

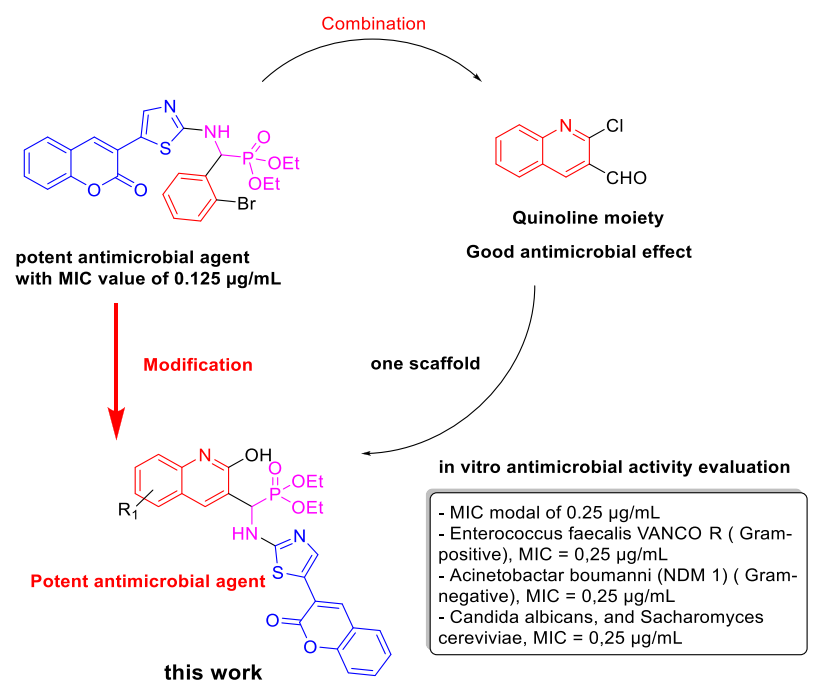

Keywords Coumarylthiazole $\cdot \alpha$-Aminophosphonates $\cdot$ Quinoline $\cdot$ Antimicrobial activity $\cdot$ Multidrug resistant

\section{Introduction}

According to the World Health Organization (WHO), bacterial infections are among the top ten causes of morbidity and mortality worldwide [1]. Data from the WHO have revealed that more than 2 million infections with a death toll of 29,000 occurring in the US per annum are directly related to bacterial infections, and cost more than $\$ 4.7$ billion $[2,3]$. Although there are many antimicrobial drugs currently in use in clinical medicine, they become less effective in a short time because microorganisms rapidly develop resistance mechanisms [4]. Based on these facts, the discovery of new and effective drugs must be discovered to overcome bacterial resistance and develop effective treatments [5].

Quinoline belongs to a biologically active class of compounds as they show quite diverse biological activities [6]. Many scientific reports revealed that natural and synthetic quinolines are drawn considerable attention in medicinal chemistry [7, 8]. The great attention paid by researchers to the study of quinoline derivatives is explained by their broad range of biological activities, such as antiAlzheimer [9], antidiabetic [10], anti-inflammatory [11], antituberculosis [12], anticancer [13], antioxidant [14], and as inhibitors of SARS-CoV-2 (COVID-19) virus [15-17]. Therefore, compounds containing thiazole heterocycles are well known in medicinal chemistry [18], thiazole derivatives exhibit significant biological activities, such as antimicrobial and antimalarial [19], Alzheimer [20], antiproliferative agents [21], anticancer agents [22], and anti-inflammatory [23]. In addition, coumarins are an important class of heterocyclic compounds with various biological activities [24]. The combination of coumarin and a thiazole ring is of great significance in pharmaceutical chemistry. Coumarin-thiazole compounds have shown many biological activities such as anti-acetylcholinesterase [25], anti-inflammatory [26], antibacterial and antituberculosis agents [27], antioxidant, and inhibition of carbonic anhydrase [28, 29] (Fig. 1).

Recently, $\alpha$-aminophosphonates have received enormous attention from scientific researchers in pharmaceutical and medicinal chemistry [30], due to structural analogies to amino acids and exhibit many biological properties [31], such as anti-Alzheimer [32], antimicrobial [33], antiviral [34], and antioxidant [35]. The Kabachnik-Fields reaction is one and the simplest of the most practical approaches for $\alpha$-aminophosphonate syntheses; the reaction generally requires various catalysts, such as $\mathrm{CF}_{3} \mathrm{CO}_{2} \mathrm{H}$ [36], $\mathrm{TiO}_{2}$ [37], Amberlite-IR 120 [38], $\mathrm{SnCl}_{2}$ [39], phenyl phosphonic acid [40], and ethyl lactate [41]. However, many of these catalysts are expensive and have to be used in stoichiometric amounts. The green catalyst synthesis of $\alpha$-aminophosphonates is rather limited [42].

Based on these facts and keeping in view the wide range of biological activities of quinoline or quinolone, thiazole moieties, and aminophosphonate scaffolds, in this work, we expect that the incorporation of all these moieties in the same scaffold structure may lead to good activities and potent antibacterial agents. Thus, we have designed and synthesized a series of novel $\alpha$-aminophosphonates derivatives bearing quinoline or quinolone rings, and thiazole moieties were evaluated against references and multidrug-resistant bacteria and fungal strain. 
Fig. 1 Biological applications of compounds containing coumarylthiazole, quinoline, and phosphonate moieties<smiles>CCN(CCO)CCCC(C)Nc1ccnc2cc(Cl)ccc12</smiles>

hydroxyqloroquine

Antimalarial and Anti SARS-CoV-2

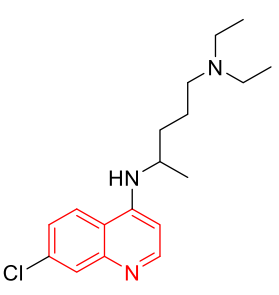

chloroquine

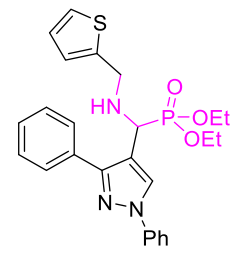

$\mathrm{Ph}$

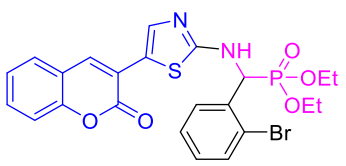

coumarylthiazole-aminophosphonate moiety

potent antimicrobial with $\mathrm{MIC}=0.125 \mu \mathrm{g} / \mathrm{mL}$ against $P$ seudomonas aeruginosa imipenemresistant (VIM-2.1)

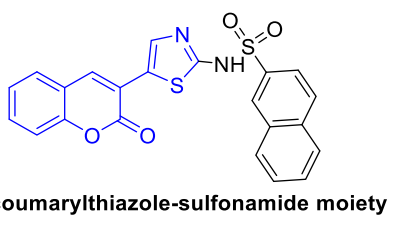

coumarylthiazole-sulfonamide moiety aminophosphonate as Alzheimer agent

\section{Results and discussions}

\section{Chemistry}

Two series of 12 novel $\alpha$-aminophosphonate $(\mathbf{9 a}-\mathbf{h})$ and (10i-l) derivatives that incorporated quinoline or quinolone, and coumarylthiazole or 5-phenylthiazol-2-amine moieties were designed and synthesized by condensation of three components via one-pot Kabachnik-Fields reaction under ultrasound (US) irradiation. Our design strategy was based on the synthesis of novel $\alpha$-aminophosphonates moiety containing quinoline or quinolone scaffold to improving the biological activity against microbial strains.

The synthesis of all intermediates and target molecules was performed according to the reactions outlined in Schemes 1-3. The first step of the synthesis involved formation of aldehyde derivatives (quinoline and quinolone) and functionalized 3-(2-aminothiazol-5-yl)-2H-chromen-2one (3) and 5-phenylthiazol-2-amine (5). The reaction to give the target compound $(\mathbf{9 a}-\mathbf{h})$ and $(\mathbf{1 0 i}-\mathbf{l})$ derivatives was started from 3-(2-aminothiazol-5-yl)-2H-chromen-2one (3) or 5-phenylthiazol-2-amine (5), respectively, quinoline/quinolone carbaldehyde, and triethylphosphite under US irradiation using ionic liquid triethylammonium acetate [TEAA] as a catalyst at room temperature (Scheme 3 ).

The 3-(2-aminothiazol-5-yl)-2H-chromen-2-one (3) and 5-phenylthiazol-2-amine (5) presented in this study were obtained from a simple and efficient methodology described in the literature [43] as shown in Scheme 1. At first, 3-acetylcoumarin (1) was obtained by the condensation between salicylaldehyde and ethyl acetoacetate in ethanol at $0-5{ }^{\circ} \mathrm{C}$ in the presence of a catalytic amounts of piperidine. The second precursors, 3-(2-bromoacetyl)-2H-chromen-2-

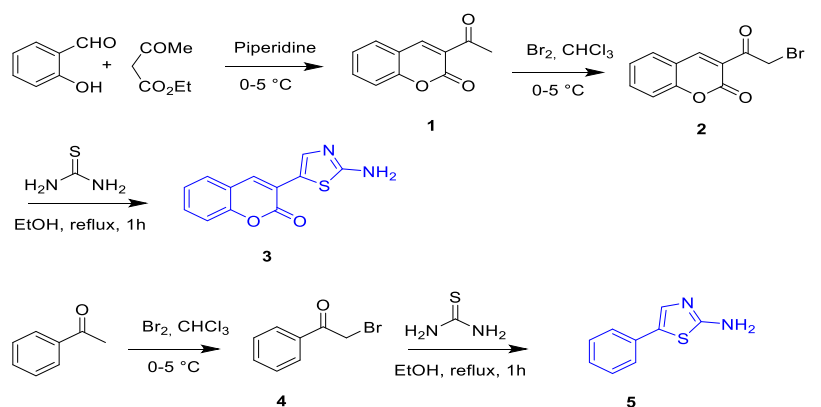

Scheme 1 Synthesis of 3-(2-aminothiazol-5-yl)-2H-chromen-2-one (3) and 5-phenylthiazol-2-amine (5)

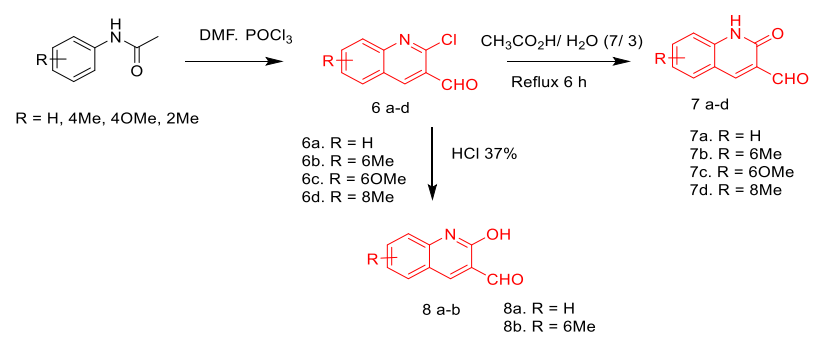

Scheme 2 Synthesis of quinoline and quinolone derivatives

one (2) and 2-bromo-1-phenylethan-1-one (4), were synthesized by brominating 3-acetylcoumarin and acetophenone respectively in chloroform. 3-(2-Aminothiazol-5yl)-2H-chromen-2-one (3) and 5-phenylthiazol-2-amine (5) were obtained by reaction of compounds (2) and (4) with thiourea in ethanol and neutralized with ammonia. 2-Chloroquinoline-3-carbaldehyde derivatives $(\mathbf{6 a}-\mathbf{d})$ were obtained via Meth-Cohn reaction [44], which included the condensation of acetanilide derivatives with Vilsmeier-Haack 
Scheme 3 Synthesis of new $\alpha$ aminophosphonate quinolone/ quinolone thiazole derivatives: (i) aldehyde $(1 \mathrm{mmol})$, amine (1 mmol), triethylphosphite (TEP) (1 mmol), ILs (TEAA)

(1 mL), US $(40 \mathrm{kHz}), \mathrm{rt}$

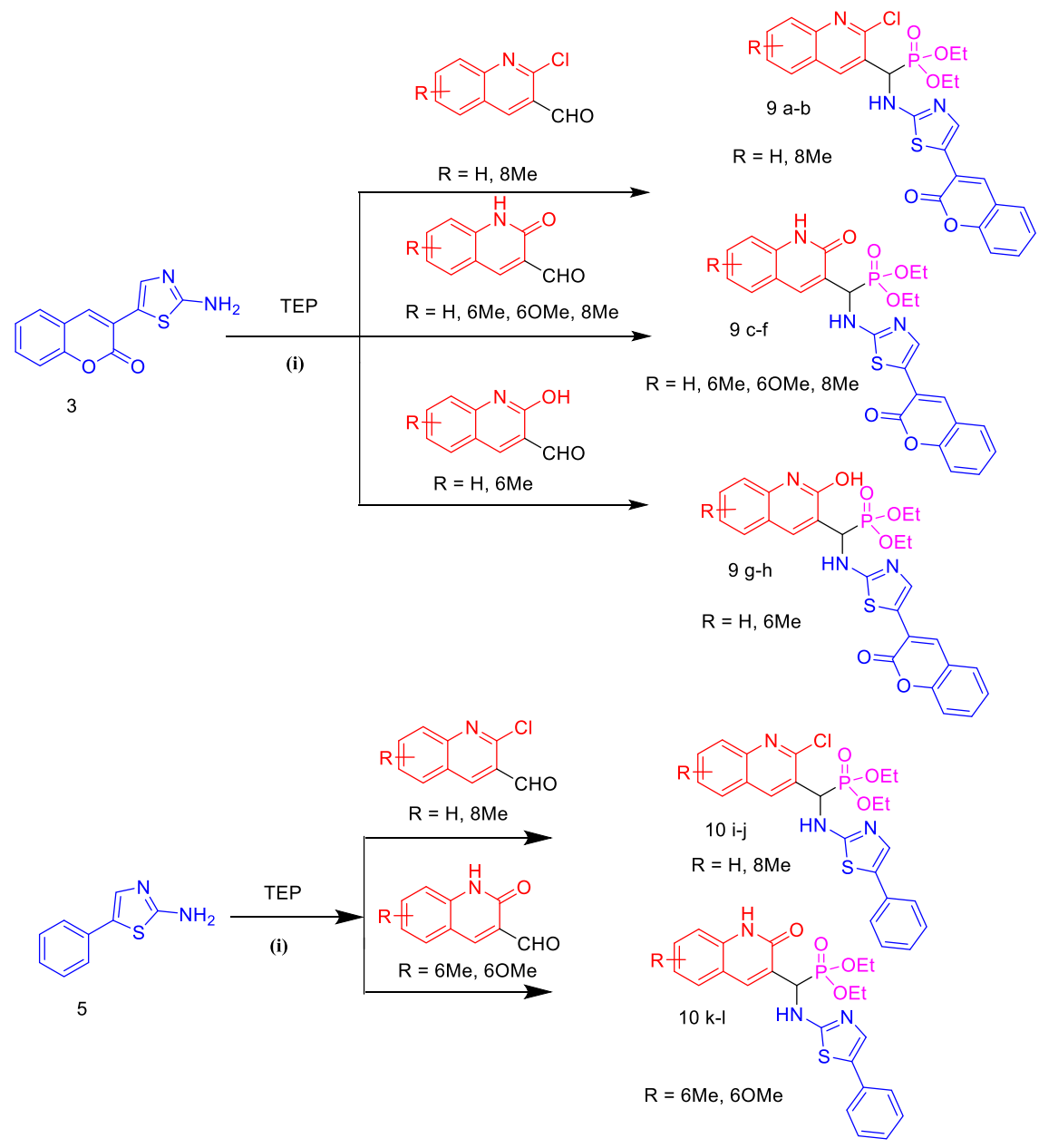

reagent. 2-Oxoquinoline-3-carbaldehyde derivatives (7a-d) were then obtained by the hydrolytic reaction of compounds $(\mathbf{6 a}-\mathbf{d})$ in the presence of $70 \%$ acetic acid [45]. As a continuation, compounds $(\mathbf{8 a}-\mathbf{b})$ were obtained when treating 2chloro-quinoline-3-carbaldehyde derivatives in the presence of Clorohydric acid ( $\mathrm{HCl} \mathrm{37 \% )} \mathrm{[46].} \mathrm{The} \mathrm{TEAA} \mathrm{has} \mathrm{been}$ easily prepared from the reaction of triethylamine and acetic acid $\left(\mathrm{CH}_{3} \mathrm{CO}_{2} \mathrm{H}\right)$ according to the reported method [47], and was found in excellent yield $98 \%$.

Finally, compounds $(\mathbf{9 a}-\mathbf{h})$ and $(\mathbf{1 0} \mathbf{i}-\mathbf{l})$ were obtained when compounds (3) and (5) were reacted with an aldehyde (quinoline or quinolone derivatives), and triethylphosphite via one-pot Kabachnik-Fields reaction under US irradiation in the presence of ionic liquid [TEAA] as a catalyst (Scheme 3).

In continuation of our previous research project [48, 49] toward the development and synthesis of novel biomolecule compounds contain $\alpha$-aminophosphonate moiety in high yields and clean conditions, in this study, we reported and used our previous strategy for the synthesis of new $\alpha$-aminophosphonate $(\mathbf{9 a}-\mathbf{h})$ and $(\mathbf{1 0} \mathbf{i}-\mathbf{l})$ derivatives using the ionic liquid [TEAA] under US irradiation. We have found that the ionic liquid [TEAA] presented several advantages for the synthesis of $\alpha$-aminophosphonate derivatives, such as giving pure product without chromatography purification and excellent yield in short reaction time with a simple workup.

All the new compounds $(\mathbf{9 a}-\mathbf{h})$ and $(\mathbf{1 0 i}-\mathbf{l})$ were characterized and confirmed by spectroscopic techniques infrared [IR], 1H-nuclear magnetic resonance $\left[{ }^{1} \mathrm{H}-\mathrm{NMR}\right],{ }^{13} \mathrm{C}$ NMR, ${ }^{31} \mathrm{P}-\mathrm{NMR}$, and 2D NMR heteronuclear singlequantum coherence [HSQC], heteronuclear multiple bond correlation [HMBC], and elemental analysis. These techniques helped for determining and confirm the molecular structures of the synthesized compounds (Table 1).

From the ${ }^{1} \mathrm{H}-\mathrm{NMR}$ spectroscopic, it was possible to observe the presence of principal signals of protons in each product. The lack of the signal of the aldehyde confirmed the structure of synthetized compounds, the proton $(\mathrm{N}-\mathrm{H})$ of $\alpha$-aminophosphonates groups was detected between $\delta=9$ and $12 \mathrm{ppm}$, the signals at $\delta=1.20$ and $4.20 \mathrm{ppm}$ corresponded to methylene $\left(\mathbf{C H}_{3}-\mathrm{CH}_{2}-\mathrm{O}\right)$ and ethylene $\left(\mathrm{CH}_{3}-\right.$ $\mathbf{C H}_{2}-\mathrm{O}$ ) respectively of phosphonates groups, the proton of asymmetric carbone $\left(\mathrm{P}^{*} \mathrm{CH}\right)$ is clearly detected between $\delta=5.90$ and $6.20 \mathrm{ppm}$, the signals at $\delta=7.50 \mathrm{ppm}$ 
Table 1 Synthesis of novel $\alpha$-aminophosphonate $(9 \mathrm{a}-\mathrm{h})$ and $(10 \mathrm{i}-1)$ derivatives under ultrasound irradiation in ionic liquid TEAA

\begin{tabular}{|c|c|c|c|c|c|}
\hline Entry & Aldehyde (quinoline/quinolone) & Thiazole derivatives & Time (min) & Yield $(\%)^{\mathrm{a}}$ & m.p. $\left({ }^{\circ} \mathrm{C}\right)$ \\
\hline 9a & & & 17 & 73 & $237-238$ \\
\hline $9 b$ & & & 22 & 70 & $130-132$ \\
\hline 9c & & & 15 & 86 & 204-205 \\
\hline 9d & & & 13 & 84 & $275-276$ \\
\hline $9 e$ & & & 10 & 83 & $242-244$ \\
\hline $9 f$ & $\mathrm{H}$ & & 16 & 85 & $152-154$ \\
\hline $9 \mathrm{~g}$ & & & 23 & 78 & $173-177$ \\
\hline $9 h$ & & & 19 & 71 & $209-210$ \\
\hline $10 \mathbf{i}$ & & & 14 & 88 & $201-203$ \\
\hline $10 \mathbf{j}$ & & & 16 & 84 & $131-132$ \\
\hline
\end{tabular}


Table 1 (continued)

\begin{tabular}{|c|c|c|c|c|c|}
\hline Entry & Aldehyde (quinoline/quinolone) & Thiazole derivatives & Time (min) & Yield $(\%)^{\mathrm{a}}$ & m.p. $\left({ }^{\circ} \mathrm{C}\right)$ \\
\hline $10 k$ & & & 14 & 90 & $272-274$ \\
\hline 101 & & & 18 & 89 & $138-139$ \\
\hline
\end{tabular}

Conditions: aldehyde (quinoline/quinolone) $(1 \mathrm{mmol})$, amine $(1 \mathrm{mmol})$, triethylphosphite $(1 \mathrm{mmol})$, ILs (triethylammonium acetate) $(1 \mathrm{~mL})$, $40 \mathrm{kHz}$

${ }^{a}$ Yield (\%): a yield of isolated product

corresponded to the protons of thiazole rings. For compounds $(\mathbf{9 a}-\mathbf{h})$, we detected that signals at $\delta=8.50 \mathrm{ppm}$ corresponded to coumarin rings, compounds containing quinolone and 2-hydroxyquinoline moiety showed that the signals at $\delta=11.98$ and $11.80 \mathrm{ppm}$ corresponded for $(\mathrm{N}-\mathbf{H})$ and (O-H) hydroxyl groups of quinolone and 2-hydroxyquinoline moiety, respectively. However, for all synthesized compounds the last type of protons of aromatic rings is located between $\delta=7.4$ and $8.45 \mathrm{ppm}$. The ${ }^{13} \mathrm{C}-\mathrm{NMR}$ spectroscopic analysis of all new compounds also confirmed that structural identity by observing the new characteristic type of doublets signals at $\delta=16.50$ and $63.20 \mathrm{ppm}$ corresponded for methylene $\left(\mathbf{C H}_{3}-\mathrm{CH}_{2}-\mathrm{O}-\mathbf{P}\right)$ and ethylene $\left(\mathrm{CH}_{3}-\mathbf{C H}_{2}-\mathrm{O}-\mathbf{P}\right)$ respectively due to the coupling of the carbon atoms with the phosphorus atoms $\left(\mathbf{J}_{\mathbf{C}-\mathbf{P}}\right)$, the peak corresponded the asymmetric carbone $\left(\mathrm{P}^{*} \mathbf{C H}\right)$ was observed at $\delta=46 \mathrm{ppm}$, the peaks corresponded to coumarin lactone and thiazole ring detected at $\delta=138$ and 142 ppm, respectively. However, compounds containing quinolone moiety showed a peak relating to the carbonyl of the amide group $(\mathrm{HN}-\mathrm{C}=\mathrm{O})$ at $\delta=160 \mathrm{ppm}$.

In the ${ }^{31} \mathrm{P}-\mathrm{NMR}$ spectrum, the phosphorus atom was resonated as a single ranging between $\delta=19$ and $21.2 \mathrm{ppm}$ approximately in all the synthesized compounds.

The structures of the representative compounds were confirmed by 2D NMR, HSQC, and HMBC. The HSQC spectra confirm the vicinal relationship $(\mathrm{C}-\mathrm{H}$ correlation 1-2) and the HMBC spectra mode indicates the $\mathrm{C}-\mathrm{H}$ correlation 1-3. The elemental analysis furthermore confirmed the assigned structures of all synthesized compounds.

\section{Antimicrobial activity}

In medicinal chemistry, the combinations of two or more pharmacophores into one scaffold are a common procedure for the discovery and development of new drugs.
Recently, quinolones/quinolones and thiazole derivatives are known for their strong antimicrobial effect and displayed good antibacterial activity [50, 51]. In contrast, the literature reports reveal that the $\alpha$-aminophosphonates derivatives displayed good and promising antimicrobial activity [49].

To identify new antimicrobial agents, our combination strategy was based on the synthesis of new $\alpha$-aminophosphonates containing quinoline or quinolone derivatives substituted with coumarylthiazole/5-phenylthiazole in the same scaffold. Moreover, we expected that the presence of $\alpha$-aminophosphonates moiety contributes to improving the antimicrobial activity against references, multidrug-resistant bacteria, and fungal strains.

The antimicrobial profile of the newly synthesized compounds $(\mathbf{9} \mathbf{a}-\mathbf{h})$ and $(\mathbf{1 0 i}-\mathbf{l})$ have been evaluated in vitro for their antibacterial activity against the selected strains of Gram-negative and Gram-positive bacteria and two fungal strains, using the broth micro-dilution method. Dimethyl sulfoxide (DMSO) was used as a negative control. For the control test, we have used Imipenem, Ciprofloxacin, Amikacin, and Fluconazole as a positive control to compare the minimal inhibitory concentration (MIC). The MIC values are reported in Tables 2 and 3 .

The results reveal that all compounds have shown excellent antimicrobial effects against both Gram-negative and Gram-positive bacteria strains compared with standard drugs (positive control). In case of a Gram-positive bacterial study, the MIC values listed in Table 2 revealed that the synthesized compounds $(\mathbf{9} \mathbf{a}-\mathbf{h})$ and $(\mathbf{1 0} \mathbf{i}-\mathbf{l})$ had promising antimicrobial profiles against Enterococcus faecalis ATCC 29212, vancomycin-resistant Enterococcus faecalis with MIC values ranging between 0.25 and $32 \mu \mathrm{g} / \mathrm{mL}$. Compound $9 \mathrm{~g}$ was found to be the most potent one against Bacillus cereus, Staphylococcus aureus resistant to ciprofloxacin, Enterococcus faecalis ATCC 29212, vancomycin- 
Table 2 MICs $(\mu \mathrm{g} / \mathrm{mL})$ values of the synthesized $\alpha$ aminophosphonates $(9 \mathrm{a}-\mathrm{h})$ and (10i-1) derivatives against the tested Gram-positive bacteria

\begin{tabular}{|c|c|c|c|c|c|c|}
\hline Compounds & $\begin{array}{l}\text { Bacillus } \\
\text { cereus }\end{array}$ & $\begin{array}{l}\text { Staph. } \\
\text { aureus } \\
\text { cip } R\end{array}$ & $\begin{array}{l}\text { Staph. aureus } \\
\text { ATCC } 25923\end{array}$ & $\begin{array}{l}\text { Staph. aureus } \\
\text { ATCC } 6538\end{array}$ & $\begin{array}{l}\text { Enterococcus } \\
\text { faecalis } \\
\text { VANCO R }\end{array}$ & $\begin{array}{l}\text { Enterococcus } \\
\text { faecalis } \\
\text { ATCC } 29212\end{array}$ \\
\hline $9 a$ & 2 & 512 & 512 & 128 & 0.5 & 0.5 \\
\hline $9 b$ & 256 & 256 & 256 & 128 & 0.5 & 2 \\
\hline $9 \mathrm{c}$ & 32 & 64 & 0.25 & ++ & 1 & ++ \\
\hline 9d & ++ & 64 & 64 & ++ & 0.25 & ++ \\
\hline $9 e$ & 32 & 32 & ++ & ++ & 0.5 & 0.5 \\
\hline $9 f$ & ++ & ++ & ++ & ++ & 0.25 & 0.5 \\
\hline $9 \mathrm{~g}$ & 2 & 0.5 & ++ & ++ & 0.25 & 0.5 \\
\hline $9 \mathrm{~h}$ & 4 & 32 & 128 & ++ & 0.5 & 0.5 \\
\hline $10 \mathbf{i}$ & ++ & 0.5 & 0.5 & 1 & 1 & 32 \\
\hline $10 \mathbf{j}$ & 128 & 8 & ++ & ++ & ++ & 1 \\
\hline $10 k$ & 2 & 256 & 256 & ++ & 1 & 0.5 \\
\hline 101 & 16 & ++ & ++ & ++ & 0.5 & 2 \\
\hline Imipenem $^{\mathrm{a}}$ & - & - & - & - & - & - \\
\hline Ciprofloxacin $^{\mathrm{a}}$ & - & - & - & - & - & - \\
\hline Amikacine $^{\mathrm{a}}$ & - & - & - & - & - & - \\
\hline Fluconazole $^{a}$ & - & - & - & - & - & - \\
\hline
\end{tabular}

++ : no inhibition (or concentration $>512 \mu \mathrm{g} / \mathrm{mL}$ ), -: not applicable

${ }^{a}$ Positive reference, $R$ resistant, $M I C$ minimum inhibitory concentration resistant Enterococcus faecalis with MIC values ranging between 0.25 and $2 \mu \mathrm{g} / \mathrm{mL}$ followed by compounds $9 \mathbf{e}, \mathbf{9 h}$, and 10i with MIC values between 0.25 and $128 \mu \mathrm{g} / \mathrm{mL}$ while other derivatives are moderately active. On the other hand, bacteria strains Staphylococcus aureus ATCC 25923 and Staphylococcus aureus ATCC 6538 exhibited less resistance against the synthesized compounds and the MIC values ranging between 0.25 and $512 \mu \mathrm{g} / \mathrm{mL}$.

In case of Gram-negative bacterial study, the MIC values listed in Table 3 revealed that all the newly synthesized compounds $(\mathbf{9 a}-\mathbf{h})$ and $(\mathbf{1 0 i}-\mathbf{l})$ exhibited broad-spectrum activity with excellent and high inhibition against all Gramnegative bacteria with MIC modal of $0.25 \mu \mathrm{g} / \mathrm{mL}$. Most of the synthesized compounds have exhibited moderate and high inhibition against Escherichia coli ESBL (enlarged specter $\beta$-lactamase) producer, Escherichia coli resistant to ciprofloxacin, Pseudomonas aeruginosa imipenem-resistant (VIM-2), Acinetobacter baumanni (NDM-1), Pseudomonas aeruginosa ATCC 9027, Enterobacter cloacae fosfomycin resistant, Klebsiella pneumoniae Carbapenem-resistant $(\mathrm{KpC}$ + ), Klebsiella pneumoniae Carbapenem-sensitive (KpC-), Serratia marcescens with MIC values ranging between 0.25 and $128 \mu \mathrm{g} / \mathrm{mL}$. Particularly, the results reveal that the compounds $9 f, 9 \mathrm{~g}, 9 \mathrm{~h}$, and $9 \mathrm{e}$ have shown the highest antibacterial activity and excellent inhibition from compounds bearing coumarylthiazole moiety $(\mathbf{9 a}-\mathbf{h})$ and compounds $\mathbf{1 0 k}$ and $\mathbf{1 0 l}$ from compounds bearing 5-phenylthiazole moiety $(\mathbf{1 0 i}-\mathbf{l})$ against Escherichia coli resistant to ciprofloxacin, Pseudomonas aeruginosa imipenem-resistant (VIM-2), Acinetobacter baumanni (NDM-1), Enterobacter cloacae fosfomycin resistant, Escherichia coli ESBL producer, Serratia marcescens bacteria strains with MIC values ranging between 0.25 and $64 \mu \mathrm{g} / \mathrm{mL}$ and even more efficient than the standard drugs Imipenem, Ciprofloxacin, and Amikacine. So most of these compounds can be considered as broad-spectrum potential antibacterial agents.

From the results of Table 3, we have found two MIC values $(\mathrm{MIC}=0.25 / 32 \mu \mathrm{g} / \mathrm{mL}$ ) for compound 9a against Salmonella typhi and two MIC values (MIC $=0.5 / 64 \mu \mathrm{g} /$ $\mathrm{mL}$ ) for compound $9 \mathrm{~g}$ against $E$. Coli ESBL producer. These results are explained by the compatibility between the permeability of the bacterial membrane and the concentration of the compound.

The in vitro antifungal activity of all the synthesized compounds $(\mathbf{9 a}-\mathbf{h})$ and $(\mathbf{1 0} \mathbf{i}-\mathbf{l})$ was screened against two fungal strains Candida albicans and Saccharomyces ceriviceae using the drug Fluconazole as a reference standard (positive control). The results listed in Table 4 clearly showed that all the tested compounds had excellent antifungal effects against the different fungal strains ranging between 0.25 and $32 \mu \mathrm{g} / \mathrm{mL}$. The highest activity was observed with the compounds $9 \mathrm{~b}, 9 \mathrm{c}, 9 \mathrm{f}, 9 \mathrm{~g}, 9 \mathrm{~h}$ and $\mathbf{1 0 k}$, $\mathbf{1 0 l}$ from compounds bearing both coumarylthiazole moiety $(\mathbf{9 a}-\mathbf{h})$ and 5-phenylthiazole moiety (10i-l), respectively, with MIC ranging between 0.25 and $32 \mu \mathrm{g} / \mathrm{mL}$ less and much better than the drug fluconazole $2 \mu \mathrm{g} / \mathrm{mL}$, and based on these facts we can consider most of the synthesized compounds as potential antifungal agents candidates. 


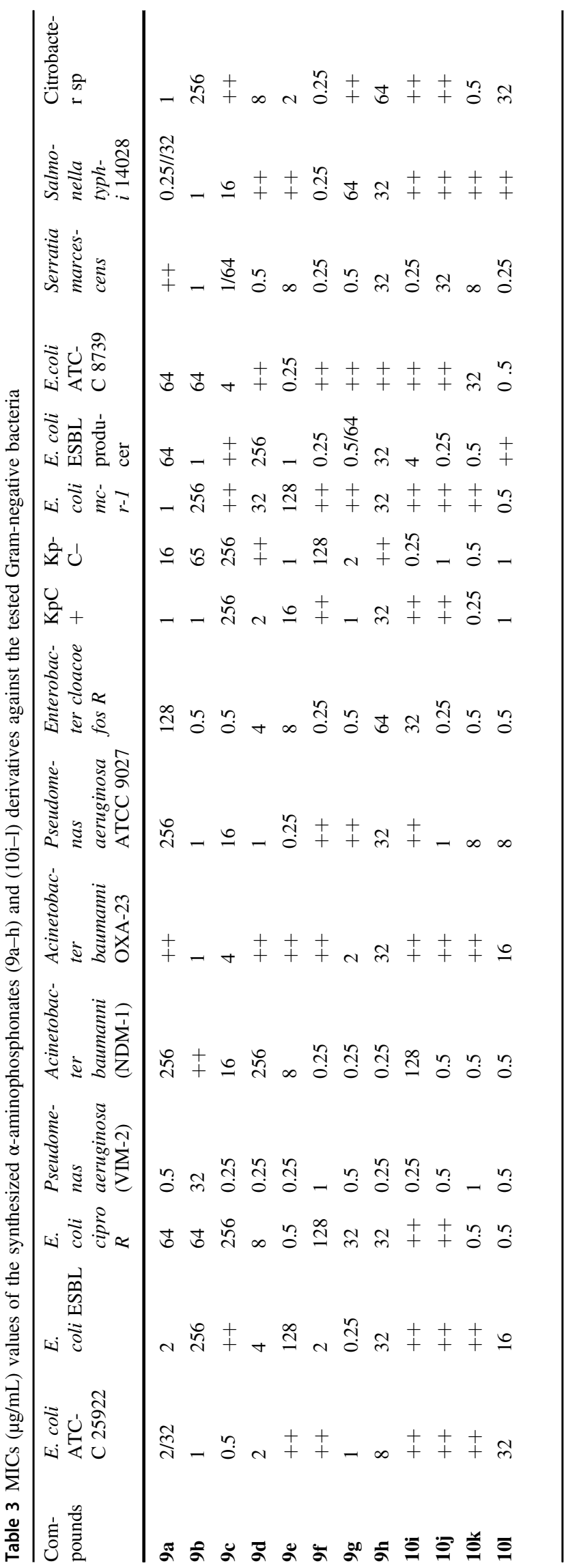

It is important to highlight that the synthesized compounds $(\mathbf{9} \mathbf{a}-\mathbf{h})$ and $(\mathbf{1 0} \mathbf{i}-\mathbf{l})$ showed promising antimicrobial effects against pathogenic Gram-positive and Gramnegative and fungi strains. The results from these studies and based on the results of Tables 2 and 3, we found that the quinoline- $\alpha$-aminophosphonate derivatives substituted with coumarylthiazole/5-phenylthiazole play an important role in the antimicrobial activity.

In this study, we found that the presence of quinoline- $\alpha$ aminophosphonate moiety in the same scaffold with coumarylthiazole/5-phenylthiazole group significantly increases the antibacterial activity with interest and promise MIC values relatively low and much lower than the MIC of antibiotics used in medicine: Imipenem, Ciprofloxacin, Amikacine, and Fluconazole (Fig. 2). All the newly synthesized compounds $(\mathbf{9 a}-\mathbf{h})$ and $(\mathbf{1 0} \mathbf{-}-\mathbf{l})$ showed a modal MIC around $0.25 \mu \mathrm{g} / \mathrm{mL}$ and exhibited a broad spectrum of antimicrobial activity.

\section{Structure-activity relationship analysis}

From the in vitro antibacterial and antifungal results, the structure-activity relationship (SAR) of synthesized quinoline-aminophosphonate molecules can be derived (Fig. 3).

The following SAR observations can be drawn from data of Tables 2 and 3. In general, compounds bearing coumarylthiazole group $(\mathbf{9 a}-\mathbf{h})$ possessed much higher activity against Gram-negative and Gram-positive bacteria pathogen strains than those containing 5-phenylthiazole group (10i-l) that showed less activity against Gram-positive strains. However, the newly synthesized $\alpha$-aminophosphonates derivatives bearing 2-hydroxyquinoline and quinolone moiety were the most active and demonstrated a high antibacterial activity compared with those bearing 2-chloroquinoline moiety.

(i) The best inhibitor among the synthesized and investigated compounds was the $\alpha$-aminophosphonates derivatives bearing 2-hydroxyquinoline and coumarylthiazole group $9 \mathrm{~g}$ and $9 \mathrm{~h}$ against microbial pathogen strains. These results showed a qualitative relationship between the presence of 2-hydroxyquinoline and coumarylthiazole group in the same scaffold with MIC values ranging between 0.25 and $128 \mu \mathrm{g} / \mathrm{mL}$.

(ii) For quinolone derivatives, compounds containing quinolone and coumarylthiazole/5-phenylthiazole in the same scaffold 9e, 9f, and 10k, 10l showed interesting effects against both bacterial and fungal strains with moderate MIC values ranging between 0.25 and $128 \mu \mathrm{g} / \mathrm{mL}$ and more active than compounds bearing quinoline moiety that showed less antimicrobial activity. 
Table 4 In vitro antifungal activity results of the synthesized $\alpha$-aminophosphonates $(9 \mathrm{a}-\mathrm{h})$ and $(10 \mathrm{i}-\mathrm{l})$

\begin{tabular}{lll}
\hline Compounds & Candida albicans & Saccharomyces ceriviceae \\
\hline 9a & 8 & 32 \\
9b & 2 & 1 \\
9c & 0.25 & 0.5 \\
9d & 0.25 & 32 \\
9e & 1 & 32 \\
9f & 1 & 0.5 \\
9g & 0.5 & 1 \\
9h & 0.5 & 1 \\
$\mathbf{1 0 i}$ & ++ & 8 \\
$\mathbf{1 0 j}$ & 0.5 & 32 \\
$\mathbf{1 0 k}$ & 32 & 2 \\
$\mathbf{1 0 1}$ & 1 & 0.5 \\
Fluconazole $^{\mathrm{a}}$ & 2 & - \\
\hline
\end{tabular}

++ : no inhibition (or concentration $>512 \mu \mathrm{g} / \mathrm{mL}$ ), -: not applicable

${ }^{\text {a}}$ Positive reference, $R$ resistant, $M I C$ minimum inhibitory concentration

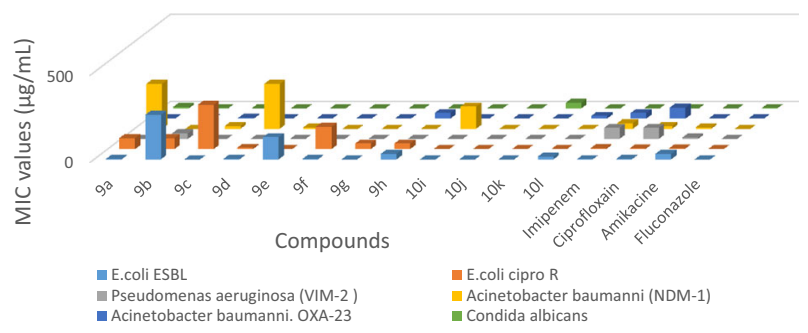

Fig. 2 Comparison of MIC values of quinoline-aminophosphonate derivatives (9a-h) and (10i-l) with standard drugs: Imipenem, Ciprofloxacin, Amikacine, and Fluconazole as reference
According to the SAR study, it is clear that the inhibitory effect is directly related to the type of the substituted group on $\alpha$-aminophosphonates moiety. The presence of quinolone and 2-hydroxyquinoline moiety can increase the inhibitory effect against microbial strains. These results confirm that the bulky substituted coumarylthiazole moiety is still more active against both references and MDR and fungal strains than 5-phenylthiazole moiety.

\section{Conclusion}

In this study, we designed, synthesized, and evaluated a series of novel scaffolds of quinoline/thiazole-derived $\alpha$ aminophosphonates for their antimicrobial activity. Among the tested compounds, compounds $9 \mathrm{e}, \mathbf{9 g}, 9 \mathrm{~h}, \mathbf{9 i}$ and $9 \mathrm{f}, \mathbf{9 g}$, 9h, 10k, 10l showed better antibacterial inhibitory activity against Gram-positive and Gram-negative bacteria strains, respectively, compared to the standard drugs Imipenem, Ciprofloxacin, Amikacine with MIC values ranging between 0.25 and $128 \mu \mathrm{g} / \mathrm{mL}$. Compounds $9 \mathbf{b}, 9 \mathbf{9 c}, 9 \mathbf{9 f}, \mathbf{9 g}$, $9 \mathrm{~h}, 10 \mathrm{k}$, and $10 \mathrm{l}$ were the most potent derivatives with MIC values ranging from 0.25 to $32 \mu \mathrm{g} / \mathrm{mL}$ against the two tested fungal strains compared to the standard drug fluconazole. According to the SAR analysis, the inhibitory activity of the synthesized compounds could also be affected by the type of substituent. The presence of coumarylthiazole moiety, and hydroxyl in the quinoline group increased the inhibitory activity against all tested microbial strains pathogens. It can be concluded that most of the synthesized compounds showed potent antimicrobial activities against the tested pathogenic strains. Subsequently, these results can help researchers to look for new potent antimicrobial agents for therapeutic use.

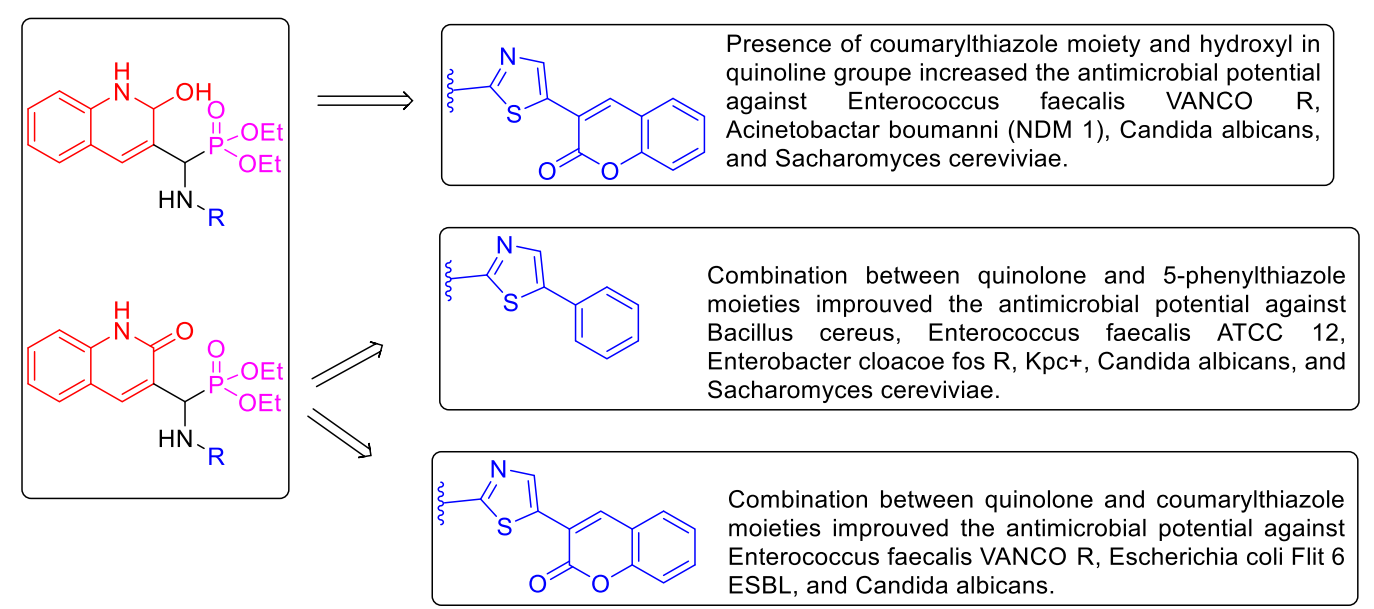

Fig. 3 Structural requirements for the antimicrobial activity of synthesized quinoline-aminophosphonate derivatives $(\mathbf{9 a}-\mathbf{h})$ and $(\mathbf{1 0 i}-\mathbf{l})$ 


\section{Experimental section}

\section{General}

All chemicals reagents used for synthesis were obtained from commercial sources and purchased from Merck, Sigma-Aldrich, and Fluka and were used without purification. Melting points (m.p.) of the synthesized compounds were taken by the Buchi Melting Point B-545 apparatus and the values are uncorrected. US irradiation was performed in a FUNGILAB ultrasonic bath with a frequency of $40 \mathrm{kHz}$ and output power of $250 \mathrm{~W}$. IR spectra were registered on Perkin-Elmer FT-600 spectrometer. ${ }^{1} \mathrm{H},{ }^{13} \mathrm{C},{ }^{31} \mathrm{P}$ spectra were recorded on a Bruker spectrometers at 400,101, and $162 \mathrm{MHz}$, respectively, in $\delta$ ppm using TMS as internal standard. Elemental analyses $(\mathrm{C}, \mathrm{H}$, and $\mathrm{N}$ ) were carried out with a Perkin-Elmer 2400 CHN elemental analyzer model 1106. Coupling constants $\mathbf{J}$ are in Hertz. Multiplicity is indicated by one of the following: s (singlet), d (doublet), t (triplet), q (quartet), dd (doublet of doublet), ddd (doublet of doublet of doublet), $m$ (multiplet), and chemical shifts are given in ppm and calibrated with DMSO- $\mathrm{d}_{6}$. All reactions were monitored by thin-layer chromatography with silica gel Merck 60 F254 percolated aluminum plates $(0.25 \mathrm{~mm})$. The visualization was performed with a UV light at $254 \mathrm{~nm}$ and ninhydrin solution as developing agents.

\section{Synthesis of 3-acetylcoumarin (1)}

A mixture of salicylaldehyde $(1 \mathrm{mmol})$ and ethyl acetoacetate $(1.2 \mathrm{mmol})$ was cooled and maintained at $0-5^{\circ} \mathrm{C}$. Few drops of piperidine were added dropwise with continuous stirring. The reaction mixture was left overnight, resulting in the formation of a yellow-colored solid that was washed by ether and purification by recrystallization $(\mathrm{EtOH} /$ $\mathrm{CHCl}_{3}$ ) 1:3 mixture gave 3-acetylcoumarin as fine yellow needles in good yields. Isolation and spectral data of this compound were reported in the literature $[27,52]$.

\section{Synthesis of 3-(bromoacetyl)-coumarin (2) and 2- bromo-1-phenylethan-1-one (4)}

3-(Bromoacetyl)-coumarin (II) and 2-bromo-1-phenylethan-1one were prepared by the methods reported in the literature [53]. 3-Acetylcoumarin $\mathbf{1}(10 \mathrm{mmol})$ and acetophenone $(10 \mathrm{mmol})$ were dissolved in alcohol-free chloroform $(20 \mathrm{~mL})$ and a solution of bromine $(10 \mathrm{mmol})$ in chloroform $(5 \mathrm{~mL})$ was added dropwise from a dropping funnel. The mixture was stirred at room temperature for $15 \mathrm{~min}$, then the mixture was heated for $20 \mathrm{~min}$ on a water-bath to expel most of the hydrogen bromide. The solid obtained was washed by ether and purification by recrystallization from glacial acetic acid gave 3-(bromoacetyl)-coumarin or 2-bromo-1-phenylethan-1one as white shiny needles in good yields.

\section{Synthesis of 3-(2-amino-1,3-thiazol-4-yl)coumarin (3) and 5-phenylthiazol-2-amine (5)}

3-(2-Amino-1,3-thiazol-4-yl)coumarin and 5-phenylthiazol-2amine were prepared by a mixture of Thiourea $(5 \mathrm{mmol})$ and a solution of 3-(bromoacetyl)-coumarin $(5 \mathrm{mmol})$ or 2-bromo1-phenylethan-1-one in boiling ethanol $(20 \mathrm{~mL})$. The mixture was refluxed for $1 \mathrm{~h}$, then cooled and neutralized with aqueous ammonia $\left(\mathrm{NH}_{4} \mathrm{Cl}\right)$. The solid obtained was filtered off and washed with ethanol without recrystallization or other purification. The product was obtained in $90 \%$ yield [54].

\section{3-(2-Amino-1,3-thiazol-4-yl)coumarin (3)}

It was obtained as a yellow powder. Yield: 90\%; m.p. 228-229 ${ }^{\circ} \mathrm{C} ;{ }^{1} \mathrm{H}-\mathrm{NMR}\left(400 \mathrm{MHz}\right.$, DMSO- $\left.d_{6}\right) \delta 8.51(\mathrm{~s}, 1 \mathrm{H})$, $7.82(\mathrm{~d}, J=7.7 \mathrm{~Hz}, 1 \mathrm{H}), 7.61(\mathrm{ddd}, J=8.9,7.3,1.7 \mathrm{~Hz}, 1 \mathrm{H})$, $7.51(\mathrm{~s}, 1 \mathrm{H}), 7.43(\mathrm{~d}, J=8.3 \mathrm{~Hz}, 1 \mathrm{H}), 7.37(\mathrm{td}, J=7.5$, $1.1 \mathrm{~Hz}, 1 \mathrm{H}), 7.19(\mathrm{~s}, 2 \mathrm{H}) ;{ }^{13} \mathrm{C}-\mathrm{NMR}\left(101 \mathrm{MHz}\right.$, DMSO- $\left.d_{6}\right) \delta$ $167.93,159.21,152.66,138.60,131.94,131.47,129.14$, 125.14, 120.87, 119.75, 116.71, 116.28, 109.18.

\section{General procedure for the synthesis of quinoline derivatives $(6 a-d)$}

To a solution of dimethylformamide ( $3 \mathrm{eq}$ ) in a flask equipped with a drying tube at $0{ }^{\circ} \mathrm{C}$, phosphorus oxychloride $\left(\mathrm{POCl}_{3}\right)(7 \mathrm{eq})$ was added dropwise with stirring. Then, to this solution, add acetanilide derivatives $(1 \mathrm{mmol})$. The reaction mixture was stirred and refluxed at $80-90{ }^{\circ} \mathrm{C}$ for a time ranging between 4 and $15 \mathrm{~h}$. After the completion reaction, the mixture was cooled and poured in ice-cold water and stirred for $30 \mathrm{~min}$, and then filtered and washed well with water and dried. The compounds were purified by recrystallization from either ethyl acetate.

2-Chloro-3-formyl-6-méthylquinoline (6b)

It was obtained as a yellow powder. Yield: $92 \% ;{ }^{1} \mathrm{H}-\mathrm{NMR}$ $\left(400 \mathrm{MHz}, \mathrm{DMSO}-d_{6}\right) \delta 10.36(\mathrm{~s}, 1 \mathrm{H}), 8.83(\mathrm{~s}, 1 \mathrm{H}), 8.00(\mathrm{t}$, $J=1.4 \mathrm{~Hz}, 1 \mathrm{H}), 7.92(\mathrm{~d}, J=8.6 \mathrm{~Hz}, 1 \mathrm{H}), 7.82(\mathrm{dd}, J=8.6$, $2.0 \mathrm{~Hz}, 1 \mathrm{H}), 2.55-2.49(\mathrm{~m}, 3 \mathrm{H}) ;{ }^{13} \mathrm{C}-\mathrm{NMR}(101 \mathrm{MHz}$, DMSO- $\left.d_{6}\right) \delta 189.88,148.54,147.66,141.03,138.56$, 136.44, 129.13, 127.96, 126.77, 21.51.

\section{General procedure for the synthesis of quinolone derivatives $(7 a-d)$}

2-Chloro-3-formyl quinoline derivatives were treated with $70 \%$ acetic acid $\left(\mathrm{CH}_{3} \mathrm{CO}_{2} \mathrm{H}\right)$ aqueous solution $(200 \mathrm{~mL})$ 
between 70 and $95{ }^{\circ} \mathrm{C}$ for $12 \mathrm{~h}$. Then the solution was cooled to room temperature and filtered off without recrystallization. The products were obtained in excellent yield.

6-Methoxy-2-oxo-1,2-dihydroquinoline-3-carbaldehyde (7c)

It was obtained as an orange powder; yield: $85 \% ;{ }^{1} \mathrm{H}-\mathrm{NMR}$ (400 MHz, DMSO- $d_{6}$ ) $\delta 12.12(\mathrm{~s}, 1 \mathrm{H}), 10.25(\mathrm{~d}, J=0.8 \mathrm{~Hz}$, $1 \mathrm{H}), 8.42(\mathrm{~s}, 1 \mathrm{H}), 7.44(\mathrm{dd}, J=2.2,1.1 \mathrm{~Hz}, 1 \mathrm{H}), 7.31(\mathrm{~d}$, $J=2.3 \mathrm{~Hz}, \quad 2 \mathrm{H}), \quad 3.80 \quad(\mathrm{~s}, \quad 3 \mathrm{H}) ;{ }^{13} \mathrm{C}-\mathrm{NMR} \quad(101 \mathrm{MHz}$, DMSO- $\left.d_{6}\right) \delta 190.31,161.51,154.97,142.15,136.49$, 126.20, 124.07, 119.13, 117.25, 111.58, 56.01 .

\section{General procedure for the synthesis of quinoline derivatives $(\mathbf{8 a}-\mathbf{b})$}

2-Hydroxy-1,2-dihydroquinoline-3-carbaldehyde derivatives were prepared by mixture of $(5 \mathrm{mmol})$ of 2 chloroquinoline-3-carbaldehyde derivatives with $20 \mathrm{~mL}$ of clorohydric acid ( $\mathrm{HCl} 37 \%)$ at reflux for $16 \mathrm{~h}$. Excess water was added, and the reaction was stirred at room temperature for $45 \mathrm{~min}$ to have a yellow precipitate. The product is recovered directly after vacuum filtration and dried.

\section{2-Hydroxy-6-methyl-1,2-dihydroquinoline-3-carbaldehyde (8b)}

It was obtained as a yellow powder; yield: $85 \% ;{ }^{1} \mathrm{H}-\mathrm{NMR}$ $\left(400 \mathrm{MHz}, \mathrm{DMSO}-d_{6}\right) \delta 12.14(\mathrm{~s}, 1 \mathrm{H}), 10.24(\mathrm{~s}, 1 \mathrm{H}), 8.41$ $(\mathrm{d}, J=0.6 \mathrm{~Hz}, 1 \mathrm{H}), 7.71-7.66(\mathrm{~m}, 1 \mathrm{H}), 7.49$ (dd, $J=8.5$, $2.0 \mathrm{~Hz}, 1 \mathrm{H}), 7.27(\mathrm{~d}, J=8.4 \mathrm{~Hz}, 1 \mathrm{H}), 2.35(\mathrm{~s}, 3 \mathrm{H})$; ${ }^{13} \mathrm{C}-\mathrm{NMR}\left(101 \mathrm{MHz}, \mathrm{DMSO}-d_{6}\right) \delta 190.28,161.81,142.52$, $139.75, \quad 135.59, \quad 132.22, \quad 130.49, \quad 126.02, \quad 118.55$, 115.82, 20.74.

\section{General procedure for the synthesis of $a-$ aminophosphonates derivatives (9a-h) and (10i-l)}

In a $10 \mathrm{~mL}$ round bottom flask taken a mixture of aldehyde derivatives (quinoline or quinolone) $(1 \mathrm{mmol})$ with $1 \mathrm{mmol}$ of 3-(2-amino-1,3-thiazol-4-yl)coumarin or 5-phenylthiazol-2-amine, and TEAA $(1 \mathrm{~mL})$ as a catalyst at room temperature. Then triethylphosphite $(1 \mathrm{mmol})$ was added. The reaction mixture was exposed to US irradiation for the appropriate time. After completion of the reaction, as indicated by TLC, $5 \mathrm{~mL}$ of distilled water was added to the mixture. The ionic liquid was dissolved in water and filtered off. The separated product was washed with water. The solid product was purified by recrystallization in ethanol. Compounds (9a-h) and (10i-l) were obtained with $70-88 \%$ yield.
Diethyl((2-chloroquinolin-3-yl)((5-(2-oxo-2H-chromen-3-yl) thiazol-2-yl)amino)methyl)phosphonate (9a)

It was obtained as a white powder; yield: 73\%; m.p. $237-238^{\circ} \mathrm{C}$; ${ }^{1} \mathrm{H}-\mathrm{NMR}\left(400 \mathrm{MHz}, \mathrm{DMSO}-d_{6}\right) \delta 9.12$ (dd, $J=8.7,5.4 \mathrm{~Hz}, 1 \mathrm{H}), 8.59(\mathrm{~d}, J=3.7 \mathrm{~Hz}, 2 \mathrm{H}), 8.06-7.93$ (m, 2H), 7.93-7.70 (m, 2H), 7.72-7.63 (m, 1H), $7.62(\mathrm{td}$, $J=7.7,1.6 \mathrm{~Hz}, 1 \mathrm{H}), 7.59(\mathrm{~s}, 1 \mathrm{H}), 7.42(\mathrm{dt}, J=7.3,3.1 \mathrm{~Hz}$, $2 \mathrm{H}), 6.14(\mathrm{dd}, J=22.0,8.6 \mathrm{~Hz}, 1 \mathrm{H}), 4.20(\mathrm{dq}, J=8.5$, $7.1 \mathrm{~Hz}, 2 \mathrm{H}), 4.09-3.95(\mathrm{~m}, 1 \mathrm{H}), 3.98-3.82(\mathrm{~m}, 1 \mathrm{H}), 1.27(\mathrm{t}$, $J=7.0 \mathrm{~Hz}, \quad 3 \mathrm{H}), 1.07 \quad(\mathrm{t}, \quad J=7.0 \mathrm{~Hz}, \quad 3 \mathrm{H}) ;{ }^{13} \mathrm{C}-\mathrm{NMR}$ $\left(101 \mathrm{MHz}, \quad\right.$ DMSO- $\left.d_{6}\right) \delta 166.36 \quad\left(\mathrm{~d}, \quad J_{C-P}=13.8 \mathrm{~Hz}\right)$, $159.04,152.70,150.56\left(\mathrm{~d}, J_{C-P}=6.8 \mathrm{~Hz}\right), 146.69,142.98$, $138.77,138.42\left(\mathrm{~d}, J_{C-P}=4.9 \mathrm{~Hz}\right), 132.10,131.67,130.32$, $128.92,128.34,128.19\left(\mathrm{~d}, J_{C-P}=12.1 \mathrm{~Hz}\right), 127.20(\mathrm{~d}$, $\left.J_{C-P}=2.7 \mathrm{~Hz}\right), 125.30,120.82,119.64,116.38,111.01$, $63.77\left(\mathrm{~d}, J_{C-P}=6.8 \mathrm{~Hz}\right), 63.33\left(\mathrm{~d}, J_{C-P}=7.0 \mathrm{~Hz}\right), 53.09$, $51.53,46.11,16.77\left(\mathrm{~d}, J_{C-P}=5.3 \mathrm{~Hz}\right), 16.50\left(\mathrm{~d}, J_{C-P}=\right.$ $5.4 \mathrm{~Hz}) ;{ }^{31} \mathrm{P}-\mathrm{NMR}\left(162 \mathrm{MHz}\right.$, DMSO- $\left.d_{6}\right) \delta$ 19.74; Anal. Calcd. for $\mathrm{C}_{26} \mathrm{H}_{23} \mathrm{ClN}_{3} \mathrm{O}_{5} \mathrm{PS}$ : C, 57.17; H, 4.17; N, 7.56. Found: C, 55.69; H, 4.38; N, 7.43.

Diethyl((2-chloro-8-methylquinolin-3-yl)((5-(2-oxo-2Hchromen-3-yl)thiazol-2-yl)amino)methyl)phosphonate (9b)

It was obtained as a green powder; yield: 70\%; m.p. 130-132 ${ }^{\circ} \mathrm{C}$; ${ }^{1} \mathrm{H}-\mathrm{NMR}\left(400 \mathrm{MHz}, \mathrm{DMSO}-d_{6}\right) \delta 9.10$ (dd, $J=8.7,5.3 \mathrm{~Hz}, 1 \mathrm{H}), 8.58(\mathrm{~s}, 1 \mathrm{H}), 8.52(\mathrm{~d}, J=2.9 \mathrm{~Hz}, 1 \mathrm{H})$, $7.90(\mathrm{~d}, J=8.4 \mathrm{~Hz}, 1 \mathrm{H}), 7.75(\mathrm{dd}, J=8.0,1.6 \mathrm{~Hz}, 3 \mathrm{H})$, $7.65-7.59(\mathrm{~m}, 1 \mathrm{H}), 7.58(\mathrm{~s}, 1 \mathrm{H}), 7.51(\mathrm{dd}, J=8.4,1.6 \mathrm{~Hz}$, $1 \mathrm{H}), 7.46-7.37(\mathrm{~m}, 3 \mathrm{H}), 6.12(\mathrm{dd}, J=22.0,8.7 \mathrm{~Hz}, 1 \mathrm{H})$, $4.19(\mathrm{dq}, J=8.6,7.0 \mathrm{~Hz}, 2 \mathrm{H}), 4.05-3.77(\mathrm{~m}, 2 \mathrm{H}), 3.02(\mathrm{q}$, $J=7.3 \mathrm{~Hz}, 1 \mathrm{H}), 1.27(\mathrm{t}, J=7.0 \mathrm{~Hz}, 3 \mathrm{H}), 1.06(\mathrm{t}, J=$ $7.0 \mathrm{~Hz}, 3 \mathrm{H}) ;{ }^{13} \mathrm{C}-\mathrm{NMR}\left(101 \mathrm{MHz}, \mathrm{DMSO}-d_{6}\right) \delta 166.36(\mathrm{~d}$, $\left.J_{C-P}=13.8 \mathrm{~Hz}\right), 159.05,152.70,150.48\left(\mathrm{~d}, J_{C-P}=6.9 \mathrm{~Hz}\right)$, $147.00,142.99,141.97,138.78,138.13\left(\mathrm{~d}, J_{C-P}=4.9 \mathrm{~Hz}\right)$, $132.08,130.31,129.20,128.91,127.96,127.03,125.30$, $120.83,119.64,116.37,110.93,79.76,79.43,79.10,63.71$ $\left(\mathrm{d}, J_{C-P}=7.0 \mathrm{~Hz}\right), 63.30\left(\mathrm{~d}, J_{C-P}=6.9 \mathrm{~Hz}\right), 53.02,51.46$, $46.04,21.85,16.76\left(\mathrm{~d}, J_{C-P}=5.4 \mathrm{~Hz}\right), 16.48\left(\mathrm{~d}, J_{C-P}=\right.$ $5.3 \mathrm{~Hz}), 9.00 ;{ }^{31} \mathrm{P}-\mathrm{NMR}\left(162 \mathrm{MHz}, \mathrm{DMSO}-d_{6}\right) \delta 19.91$; Anal. Calcd. for $\mathrm{C}_{27} \mathrm{H}_{25} \mathrm{ClN}_{3} \mathrm{O}_{5} \mathrm{PS}$ : C, 56.89; H, 4.42; N, 7.37. Found: C, 56.37; H, 4.82; N, 7.54.

Diethyl((2-oxo-1,2-dihydroquinolin-3-yl)((5-(2-oxo-2Hchromen-3-yl)thiazol-2-yl)amino)methyl)phosphonate (9c)

It was obtained as a white powder; yield: $86 \%$; m.p. 204-205 ${ }^{\circ} \mathrm{C}$; ${ }^{1} \mathrm{H}-\mathrm{NMR}\left(400 \mathrm{MHz}, \mathrm{DMSO}-d_{6}\right) \delta 11.98$ (s, $1 \mathrm{H}), 8.64(\mathrm{dd}, J=9.2,3.9 \mathrm{~Hz}, 1 \mathrm{H}), 8.53(\mathrm{~s}, 1 \mathrm{H}), 8.09(\mathrm{~d}$, $J=3.5 \mathrm{~Hz}, 1 \mathrm{H}), 7.80(\mathrm{dd}, J=7.8,1.6 \mathrm{~Hz}, 1 \mathrm{H}), 7.67-7.59$ (m, 2H), 7.58 (s, 1H), $7.50(\mathrm{td}, J=7.9,7.4,1.3 \mathrm{~Hz}, 1 \mathrm{H})$, 7.46-7.36 (m, 2H), 7.35-7.29 (m, 1H), 7.19 (ddd, $J=8.1$, 
7.2, $1.1 \mathrm{~Hz}, 1 \mathrm{H}), 6.01(\mathrm{dd}, J=20.9,9.2 \mathrm{~Hz}, 1 \mathrm{H}), 4.14$ (dddd, $J=10.6,8.1,5.7,3.4 \mathrm{~Hz}, 2 \mathrm{H}), 4.11-3.91(\mathrm{~m}, 2 \mathrm{H})$, $1.23(\mathrm{t}, J=7.1 \mathrm{~Hz}, 3 \mathrm{H}), 1.13(\mathrm{t}, J=7.0 \mathrm{~Hz}, 3 \mathrm{H}) ;{ }^{13} \mathrm{C}-\mathrm{NMR}$ $\left(101 \mathrm{MHz}\right.$, DMSO- $\left.d_{6}\right) \delta 166.59\left(\mathrm{~d}, J_{C-P}=10.8 \mathrm{~Hz}\right), 161.27$ $\left(\mathrm{d}, J_{C-P}=5.4 \mathrm{~Hz}\right), 159.16,152.71,143.21,138.69\left(\mathrm{~d}, J_{C-P}\right.$ $=8.7 \mathrm{~Hz}), 137.83\left(\mathrm{~d}, J_{C-P}=6.3 \mathrm{~Hz}\right), 132.03,130.95$, $129.70,128.98,128.24,125.24,122.58,121.00,119.72$, $119.25\left(\mathrm{~d}, J_{C-P}=3.0 \mathrm{~Hz}\right), 116.40,115.49,110.34,63.25(\mathrm{~d}$, $\left.J_{C-P}=6.8 \mathrm{~Hz}\right), 63.04\left(\mathrm{~d}, J_{C-P}=6.9 \mathrm{~Hz}\right), 49.65,16.73(\mathrm{~d}$, $\left.J_{C-P}=5.5 \mathrm{~Hz}\right), \quad 16.59 \quad\left(\mathrm{~d}, \quad J_{C-P}=5.6 \mathrm{~Hz}\right) ; \quad{ }^{31} \mathrm{P}-\mathrm{NMR}$ $\left(162 \mathrm{MHz}\right.$, DMSO- $\left.d_{6}\right) \quad \delta \quad 21.40$; Anal. Calcd. for $\mathrm{C}_{26} \mathrm{H}_{24} \mathrm{~N}_{3} \mathrm{O}_{6} \mathrm{PS}: \mathrm{C}, 58.10 ; \mathrm{H}, 4.50 ; \mathrm{N}, 7.82$. Found: C, 58.66; H, 4.11; N, 7.44 .

\section{Diethyl((6-methyl-2-oxo-1,2-dihydroquinolin-3-yl)((5-(2- oxo-2H-chromen-3-yl)thiazol-2-yl)amino)methyl) phosphonate (9d)}

It was obtained as a yellow powder; yield: 84\%; m.p. $275-276{ }^{\circ} \mathrm{C}$; ${ }^{1} \mathrm{H}-\mathrm{NMR} \quad\left(400 \mathrm{MHz}\right.$, DMSO- $\left.d_{6}\right) \quad \delta \quad 11.91$ (s, $1 \mathrm{H}), 8.65$ (dd, $J=9.2,3.8 \mathrm{~Hz}, 1 \mathrm{H}), 8.53(\mathrm{~s}, 1 \mathrm{H}), 8.03$ (d, $J=3.5 \mathrm{~Hz}, 1 \mathrm{H}), 7.79(\mathrm{dd}, J=7.8,1.5 \mathrm{~Hz}, 1 \mathrm{H}), 7.62(\mathrm{ddd}$, $J=8.5,7.4,1.6 \mathrm{~Hz}, 1 \mathrm{H}), 7.58(\mathrm{~s}, 1 \mathrm{H}), 7.46-7.36(\mathrm{~m}, 3 \mathrm{H})$, $7.32(\mathrm{dd}, J=8.4,1.9 \mathrm{~Hz}, 1 \mathrm{H}), 7.22(\mathrm{~d}, J=8.4 \mathrm{~Hz}, 1 \mathrm{H})$, $6.01(\mathrm{dd}, J=20.9,9.2 \mathrm{~Hz}, 1 \mathrm{H}), 4.21-3.90(\mathrm{~m}, 4 \mathrm{H}), 2.34(\mathrm{~s}$, $3 \mathrm{H}), 1.23(\mathrm{t}, J=7.0 \mathrm{~Hz}, 3 \mathrm{H}), 1.13(\mathrm{t}, J=7.1 \mathrm{~Hz}, 3 \mathrm{H})$; ${ }^{13} \mathrm{C}-\mathrm{NMR}\left(101 \mathrm{MHz}\right.$, DMSO- $\left.d_{6}\right) \delta 166.60\left(\mathrm{~d}, J_{C-P}=\right.$ $11.0 \mathrm{~Hz}), 161.19\left(\mathrm{~d}, J_{C-P}=5.3 \mathrm{~Hz}\right), 159.16,152.70,143.21$, $138.72,137.61\left(\mathrm{~d}, J_{C-P}=6.0 \mathrm{~Hz}\right), 136.65,132.10\left(\mathrm{~d}, J_{C-P}=\right.$ $17.8 \mathrm{~Hz}), 131.61,129.59,128.97,127.67,125.23,121.00$, $119.71,119.21\left(\mathrm{~d}, J_{C-P}=2.9 \mathrm{~Hz}\right), 116.39,115.41,110.31$, $63.22\left(\mathrm{~d}, J_{C-P}=6.7 \mathrm{~Hz}\right), 63.03\left(\mathrm{~d}, J_{C-P}=6.9 \mathrm{~Hz}\right), 49.66$, $48.11,20.79,16.74\left(\mathrm{~d}, J_{C-P}=5.5 \mathrm{~Hz}\right), 16.59\left(\mathrm{~d}, J_{C-P}=\right.$ $5.5 \mathrm{~Hz}$ ); ${ }^{31} \mathrm{P}-\mathrm{NMR}\left(162 \mathrm{MHz}, \mathrm{DMSO}-d_{6}\right) \delta$ 22.12; Anal. Calcd. for $\mathrm{C}_{27} \mathrm{H}_{26} \mathrm{~N}_{3} \mathrm{O}_{6} \mathrm{PS}$ : C, 58.80; H, 4.75; N, 7.62. Found: C, 58.30; H, 4.80; N, 7.88.

\section{Diethyl((6-methoxy-2-oxo-1,2-dihydroquinolin-3-yl)((5-(2- oxo-2H-chromen-3-yl)thiazol-2-yl)amino)methyl) phosphonate (9e)}

It was obtained as an orange powder; yield: 83\%; m.p. 242-244 ${ }^{\circ} \mathrm{C}$; ${ }^{1} \mathrm{H}-\mathrm{NMR}\left(400 \mathrm{MHz}, \mathrm{DMSO}-d_{6}\right) \delta 11.89$ (s, $1 \mathrm{H}), 8.63(\mathrm{dd}, J=9.1,4.1 \mathrm{~Hz}, 1 \mathrm{H}), 8.52(\mathrm{~d}, J=6.4 \mathrm{~Hz}$, $2 \mathrm{H}), 8.05(\mathrm{~d}, J=3.5 \mathrm{~Hz}, 1 \mathrm{H}), 7.81$ (ddd, $J=15.0,7.8$, $1.6 \mathrm{~Hz}, 2 \mathrm{H}), 7.66-7.55(\mathrm{~m}, 3 \mathrm{H}), 7.52(\mathrm{~s}, 1 \mathrm{H}), 7.40$ (dt, $J=$ 19.7, $7.7 \mathrm{~Hz}, 4 \mathrm{H}), 7.30-7.23(\mathrm{~m}, 1 \mathrm{H}), 7.19-7.11(\mathrm{~m}, 4 \mathrm{H})$, $6.01(\mathrm{dd}, J=21.0,9.0 \mathrm{~Hz}, 1 \mathrm{H}), 4.22-4.13(\mathrm{~m}, 1 \mathrm{H})$, 4.17-4.06 (m, 1H), 4.10-3.91 (m, 2H), $3.79(\mathrm{~s}, 3 \mathrm{H}), 1.23(\mathrm{t}$, $J=7.0 \mathrm{~Hz}, \quad 3 \mathrm{H}), \quad 1.14 \quad(\mathrm{t}, \quad J=7.0 \mathrm{~Hz}, 3 \mathrm{H}) ;{ }^{13} \mathrm{C}-\mathrm{NMR}$ $\left(101 \mathrm{MHz}, \quad\right.$ DMSO- $\left.d_{6}\right) \quad \delta \quad 167.89,166.52 \quad\left(\mathrm{~d}, \quad J_{C-P}=\right.$ $11.1 \mathrm{~Hz}), 160.85\left(\mathrm{~d}, J_{C-P}=5.2 \mathrm{~Hz}\right), 159.18\left(\mathrm{~d}, J_{C-P}=\right.$ $8.8 \mathrm{~Hz}), 154.78,152.66\left(\mathrm{~d}, J_{C-P}=4.6 \mathrm{~Hz}\right), 143.77,143.19$, $138.64\left(\mathrm{~d}, \quad J_{C-P}=18.2 \mathrm{~Hz}\right), \quad 137.39\left(\mathrm{~d}, \quad J_{C-P}=6.2 \mathrm{~Hz}\right)$, $133.14,131.95\left(\mathrm{~d}, J_{C-P}=10.4 \mathrm{~Hz}\right), 130.06,129.03\left(\mathrm{~d}, J_{C-P}=\right.$ $18.7 \mathrm{~Hz}), 125.12,120.97\left(\mathrm{~d}, J_{C-P}=3.0 \mathrm{~Hz}\right), 120.22,119.73$ $\left(\mathrm{d}, J_{C-P}=5.8 \mathrm{~Hz}\right), 116.81,116.32\left(\mathrm{~d}, J_{C-P}=11.5 \mathrm{~Hz}\right)$, $110.31,109.50,109.19,63.23\left(\mathrm{~d}, J_{C-P}=6.6 \mathrm{~Hz}\right), 63.05(\mathrm{~d}$, $\left.J_{C-P}=6.9 \mathrm{~Hz}\right), \quad 55.96, \quad 49.74,48.19,16.74\left(\mathrm{~d}, J_{C-P}=\right.$ $5.6 \mathrm{~Hz}), 16.60\left(\mathrm{~d}, J_{C-P}=5.6 \mathrm{~Hz}\right) ;{ }^{31} \mathrm{P}-\mathrm{NMR}(162 \mathrm{MHz}$, DMSO- $\left.d_{6}\right) \delta$ 21.12; Anal. Calcd. for $\mathrm{C}_{27} \mathrm{H}_{26} \mathrm{~N}_{3} \mathrm{O}_{7}$ PS: C, 57.14; H, 4.62; N, 7.40. Found: C, 56.96; H, 4.70; N, 7.20.

\section{Diethyl((8-methyl-2-oxo-1,2-dihydroquinolin-3-yl)((5-(2- oxo-2H-chromen-3-yl)thiazol-2-yl)amino)methyl) phosphonate (9f)}

It was obtained as a green powder; yield: 85\%; m.p. $152-154{ }^{\circ} \mathrm{C}$; ${ }^{1} \mathrm{H}-\mathrm{NMR}\left(400 \mathrm{MHz}, \mathrm{DMSO}-d_{6}\right) \delta 11.90(\mathrm{~s}$, $1 \mathrm{H}), 8.61(\mathrm{dd}, J=9.3,3.8 \mathrm{~Hz}, 1 \mathrm{H}), 8.52(\mathrm{~d}, J=7.9 \mathrm{~Hz}$, $2 \mathrm{H}), 8.05(\mathrm{~d}, J=3.5 \mathrm{~Hz}, 1 \mathrm{H}), 7.81(\mathrm{ddd}, J=10.9,7.8$, $1.6 \mathrm{~Hz}, 2 \mathrm{H}$ ), 7.61 (dddd, $J=8.7,7.1,5.3,1.6 \mathrm{~Hz}, 2 \mathrm{H}$ ), 7.57 (s, 1H), $7.52(\mathrm{~d}, J=7.2 \mathrm{~Hz}, 2 \mathrm{H}), 7.47-7.32(\mathrm{~m}, 3 \mathrm{H}), 7.13$ $(\mathrm{d}, J=13.5 \mathrm{~Hz}, 2 \mathrm{H}), 7.02(\mathrm{dd}, J=8.1,1.5 \mathrm{~Hz}, 1 \mathrm{H}), 5.99$ (dd, $J=20.8,9.3 \mathrm{~Hz}, 1 \mathrm{H}), 4.22-3.89(\mathrm{~m}, 4 \mathrm{H}), 2.37$ (s, 3H), $1.17(\mathrm{dt}, J=38.5,7.0 \mathrm{~Hz}, 6 \mathrm{H}) ;{ }^{13} \mathrm{C}-\mathrm{NMR} \quad(101 \mathrm{MHz}$, DMSO- $\left.d_{6}\right) \delta 167.89,166.64,161.41\left(\mathrm{~d}, J_{C-P}=5.5 \mathrm{~Hz}\right)$, $159.19\left(\mathrm{~d}, J_{C-P}=8.4 \mathrm{~Hz}\right), 152.67\left(\mathrm{~d}, J_{C-P}=4.7 \mathrm{~Hz}\right), 143.76$, $143.21,141.14,138.75\left(\mathrm{~d}, J_{C-P}=8.0 \mathrm{~Hz}\right), 138.56,131.96$ $\left(\mathrm{d}, J_{C-P}=10.2 \mathrm{~Hz}\right), 129.05\left(\mathrm{~d}, J_{C-P}=16.0 \mathrm{~Hz}\right), 128.38$, $128.08,125.18\left(\mathrm{~d}, J_{C-P}=9.7 \mathrm{~Hz}\right), 124.01,120.97\left(\mathrm{~d}, J_{C-P}\right.$ $=3.3 \mathrm{~Hz}), 119.74\left(\mathrm{~d}, J_{C-P}=6.0 \mathrm{~Hz}\right), 117.16,116.33(\mathrm{~d}$, $\left.J_{C-P}=11.0 \mathrm{~Hz}\right), 115.21,110.28,109.19,63.19\left(\mathrm{~d}, J_{C-P}=\right.$ $6.9 \mathrm{~Hz}), 63.01\left(\mathrm{~d}, J_{C-P}=6.8 \mathrm{~Hz}\right), 21.86,16.73\left(\mathrm{~d}, J_{C-P}=\right.$ $5.5 \mathrm{~Hz}), 16.58\left(\mathrm{~d}, J_{C-P}=5.7 \mathrm{~Hz}\right) ;{ }^{31} \mathrm{P}-\mathrm{NMR}(162 \mathrm{MHz}$, DMSO- $\left.d_{6}\right) \delta$ 21.22; Anal. Calcd. for $\mathrm{C}_{27} \mathrm{H}_{26} \mathrm{~N}_{3} \mathrm{O}_{6} \mathrm{PS}$ : C, 58.80; H, 4.75; N, 7.62. Found: C, 58.22; H, 4.17; N, 7.86.

\section{Diethyl((2-hydroxy-1,2-dihydroquinolin-3-yl)((5-(2-oxo-2H-} chromen-3-yl)thiazol-2-yl)amino)methyl)phosphonate (9g)

It was obtained as a white powder; yield: 78\%; m.p. $173-177{ }^{\circ} \mathrm{C}$; ${ }^{1} \mathrm{H}-\mathrm{NMR} \quad\left(400 \mathrm{MHz}, \quad\right.$ DMSO- $\left.d_{6}\right) \quad \delta \quad 12.00$ $(\mathrm{s}, 1 \mathrm{H}), 8.65(\mathrm{dd}, J=9.2,3.9 \mathrm{~Hz}, 1 \mathrm{H}), 8.53(\mathrm{~s}, 1 \mathrm{H}), 8.10(\mathrm{~d}$, $J=3.5 \mathrm{~Hz}, 1 \mathrm{H}), 7.80(\mathrm{dd}, J=7.7,1.5 \mathrm{~Hz}, 1 \mathrm{H}), 7.63(\mathrm{ddd}$, $J=13.5,7.3,2.8 \mathrm{~Hz}, 2 \mathrm{H}), 7.58(\mathrm{~s}, 1 \mathrm{H}), 7.54-7.23(\mathrm{~m}, 5 \mathrm{H})$, $7.19(\mathrm{t}, J=7.5 \mathrm{~Hz}, 1 \mathrm{H}), 6.02(\mathrm{dd}, J=20.9,9.2 \mathrm{~Hz}, 1 \mathrm{H})$, 4.22-3.92 (m, 4H), 1.23 (t, $J=7.0 \mathrm{~Hz}, 3 \mathrm{H}), 1.14$ (t, $J=$ $7.0 \mathrm{~Hz}, 3 \mathrm{H}) ;{ }^{13} \mathrm{C}-\mathrm{NMR}\left(101 \mathrm{MHz}, \mathrm{DMSO}-d_{6}\right) \delta 166.59(\mathrm{~d}$, $\left.J_{C-P}=11.0 \mathrm{~Hz}\right), 161.28\left(\mathrm{~d}, J_{C-P}=5.2 \mathrm{~Hz}\right), 159.15,152.70$, $143.21,138.69\left(\mathrm{~d}, J_{C-P}=7.6 \mathrm{~Hz}\right), 137.83\left(\mathrm{~d}, J_{C-P}=6.0 \mathrm{~Hz}\right)$, $132.02,130.95,129.71,128.98,128.24,125.23,122.57$, $121.00,119.71,119.24,116.39,115.50,110.34,63.26(\mathrm{~d}$, $\left.J_{C-P}=6.7 \mathrm{~Hz}\right), 63.04\left(\mathrm{~d}, J_{C-P}=6.8 \mathrm{~Hz}\right), 49.66,48.11,16.73$ $\left(\mathrm{d}, J_{C-P}=5.5 \mathrm{~Hz}\right), 16.59\left(\mathrm{~d}, \quad J_{C-P}=5.6 \mathrm{~Hz}\right) ;{ }^{31} \mathrm{P}-\mathrm{NMR}$ $\left(162 \mathrm{MHz}\right.$, DMSO- $\left.d_{6}\right) \quad \delta$ 19.74; Anal. Calcd. for 
$\mathrm{C}_{26} \mathrm{H}_{26} \mathrm{~N}_{3} \mathrm{O}_{6} \mathrm{PS}: \mathrm{C}, 57.88 ; \mathrm{H}, 4.86 ; \mathrm{N}, 7.79$. Found: C, $57.72 ; \mathrm{H}, 4.56 ; \mathrm{N}, 7.68$.

\section{Diethyl((2-hydroxy-6-methyl-1,2-dihydroquinolin-3-yl)((5- (2-oxo-2H-chromen-3-yl)thiazol-2-yl)amino)methyl) phosphonate (9h)}

It was obtained as a white powder; yield: $71 \%$; m.p. 209-210 ${ }^{\circ} \mathrm{C} ;{ }^{1} \mathrm{H}-\mathrm{NMR}\left(400 \mathrm{MHz}, \mathrm{DMSO}-d_{6}\right) \delta 11.79$ (s, $1 \mathrm{H}), 7.94(\mathrm{~d}, J=3.9 \mathrm{~Hz}, 1 \mathrm{H}), 7.52-7.47(\mathrm{~m}, 1 \mathrm{H}), 7.36-7.29$ $(\mathrm{m}, 1 \mathrm{H}), 7.22(\mathrm{~d}, J=8.3 \mathrm{~Hz}, 1 \mathrm{H}), 6.15(\mathrm{dd}, J=13.9$, $6.2 \mathrm{~Hz}, 1 \mathrm{H}), 5.32-5.22(\mathrm{~m}, 1 \mathrm{H}), 4.13-3.89(\mathrm{~m}, 4 \mathrm{H}), 2.35(\mathrm{~s}$, $3 \mathrm{H}), 1.22(\mathrm{t}, J=7.0 \mathrm{~Hz}, 3 \mathrm{H}), 1.15(\mathrm{t}, J=7.0 \mathrm{~Hz}, 3 \mathrm{H})$; ${ }^{13} \mathrm{C}-\mathrm{NMR} \quad\left(101 \mathrm{MHz}\right.$, DMSO- $\left.d_{6}\right) \quad \delta 161.05\left(\mathrm{~d}, J_{C-P}=\right.$ $5.6 \mathrm{~Hz}), 137.77\left(\mathrm{~d}, J_{C-P}=6.5 \mathrm{~Hz}\right), 136.47\left(\mathrm{~d}, J_{C-P}=1.8 \mathrm{~Hz}\right)$, 132.02, 131.46, 131.07, 127.85, $119.41\left(\mathrm{~d}, J_{C-P}=3.3 \mathrm{~Hz}\right)$, $115.31,62.74\left(\mathrm{~d}, J_{C-P}=6.7 \mathrm{~Hz}\right), 62.57\left(\mathrm{~d}, J_{C-P}=6.8 \mathrm{~Hz}\right)$, $20.84,16.83,16.77,16.71 ;{ }^{31}$ P-NMR (162 MHz, DMSO- $d_{6}$ ) $\delta$ 19.90; Anal. Calcd. for $\mathrm{C}_{27} \mathrm{H}_{28} \mathrm{~N}_{3} \mathrm{O}_{6} \mathrm{PS}$ : C, 58.58; H, 5.10; N, 7.59. Found: C, 58.87; H, 4.79; N, 7.12.

\section{Diethyl ((2-chloroquinolin-3-yl)((5-phenylthiazol-2-yl) amino)methyl)phosphonate (10 i)}

It was obtained as a yellow powder; yield: 88\%; m.p. 201-203 ${ }^{\circ} \mathrm{C} ;{ }^{1} \mathrm{H}-\mathrm{NMR}\left(400 \mathrm{MHz}\right.$, DMSO- $\left.d_{6}\right) \delta 11.96(\mathrm{~s}$, $1 \mathrm{H}), 8.49(\mathrm{dd}, J=9.7,3.5 \mathrm{~Hz}, 1 \mathrm{H}), 8.08(\mathrm{~d}, J=3.6 \mathrm{~Hz}, 1 \mathrm{H})$, $7.87-7.75(\mathrm{~m}, 2 \mathrm{H}), 7.62(\mathrm{dd}, J=7.9,1.3 \mathrm{~Hz}, 1 \mathrm{H}), 7.54-7.45$ (m, 1H), 7.40-7.29 (m, 3H), 7.33-7.12 (m, 3H), $7.11(\mathrm{~s}$, $1 \mathrm{H}), 6.05(\mathrm{dd}, J=21.1,9.6 \mathrm{~Hz}, 1 \mathrm{H}), 4.21-3.86(\mathrm{~m}, 4 \mathrm{H})$, $1.20(\mathrm{t}, J=7.0 \mathrm{~Hz}, 3 \mathrm{H}), 1.12(\mathrm{t}, J=7.0 \mathrm{~Hz}, 3 \mathrm{H}) ;{ }^{13} \mathrm{C}-\mathrm{NMR}$ $\left(101 \mathrm{MHz}, \mathrm{DMSO}-d_{6}\right) \delta 168.62,167.27\left(\mathrm{~d}, J_{C-P}=10.0 \mathrm{~Hz}\right)$, $161.15\left(\mathrm{~d}, J_{C-P}=5.1 \mathrm{~Hz}\right), 149.72,138.61,137.69\left(\mathrm{~d}, J_{C-P}=\right.$ $6.2 \mathrm{~Hz}), 135.09,130.90,129.82,128.89,128.18,127.79$, $126.00\left(\mathrm{~d}, J_{C-P}=2.7 \mathrm{~Hz}\right), 122.54,119.23\left(\mathrm{~d}, J_{C-P}=3.0 \mathrm{~Hz}\right)$, $115.48,103.02,101.93,63.20\left(\mathrm{~d}, J_{C-P}=6.7 \mathrm{~Hz}\right), 62.95(\mathrm{~d}$, $\left.J_{C-P}=7.1 \mathrm{~Hz}\right), 49.44,47.89,16.70\left(\mathrm{~d}, J_{C-P}=5.5 \mathrm{~Hz}\right), 16.57$ $\left(\mathrm{d}, J_{C-P}=5.5 \mathrm{~Hz}\right) ;{ }^{31} \mathrm{P}-\mathrm{NMR}\left(162 \mathrm{MHz}, \mathrm{DMSO}-d_{6}\right) \delta 21.14$; Anal. Calcd. for $\mathrm{C}_{23} \mathrm{H}_{23} \mathrm{ClN}_{3} \mathrm{O}_{3} \mathrm{PS}: \mathrm{C}, 56.62 ; \mathrm{H}, 4.75 ; \mathrm{N}$, 8.61. Found: C, 56.11; H, 4.23; N, 8.92.

\section{Diethyl((2-chloro-8-methylquinolin-3-yl)((5-phenylthiazol-2- yl)amino)methyl)phosphonate (10j)}

It was obtained as a yellow powder; yield: $84 \%$; m.p. $131-132{ }^{\circ} \mathrm{C}$; ${ }^{1} \mathrm{H}-\mathrm{NMR}\left(400 \mathrm{MHz}, \mathrm{DMSO}-d_{6}\right) \delta 8.54(\mathrm{~d}$, $J=3.2 \mathrm{~Hz}, 1 \mathrm{H}), 8.02(\mathrm{~d}, J=8.3 \mathrm{~Hz}, 1 \mathrm{H}), 7.75(\mathrm{~d}, J=$ $1.6 \mathrm{~Hz}, 1 \mathrm{H}), 7.51(\mathrm{dd}, J=8.4,1.7 \mathrm{~Hz}, 1 \mathrm{H}), 6.64(\mathrm{dd}, J=$ $16.3, \quad 5.7 \mathrm{~Hz}, 1 \mathrm{H}), 5.37(\mathrm{dd}, J=13.6,5.7 \mathrm{~Hz}, 1 \mathrm{H})$, 4.14-3.87 (m, 4H), $2.53(\mathrm{~s}, 3 \mathrm{H}), 1.21(\mathrm{t}, J=7.1 \mathrm{~Hz}, 3 \mathrm{H})$, $1.13(\mathrm{t}, J=7.0 \mathrm{~Hz}, 3 \mathrm{H}) ;{ }^{13} \mathrm{C}-\mathrm{NMR}\left(101 \mathrm{MHz}, \mathrm{DMSO}-d_{6}\right) \delta$ $149.01\left(\mathrm{~d}, J_{C-P}=7.0 \mathrm{~Hz}\right), 147.11\left(\mathrm{~d}, J_{C-P}=2.4 \mathrm{~Hz}\right), 141.79$, $138.89\left(\mathrm{~d}, J_{C-P}=5.1 \mathrm{~Hz}\right), 130.57,130.12,128.27,126.94$, $125.40\left(\mathrm{~d}, J_{C-P}=2.8 \mathrm{~Hz}\right), 67.19,65.53,63.12\left(\mathrm{~d}, J_{C-P}=\right.$ $7.0 \mathrm{~Hz}), 62.81\left(\mathrm{~d}, J_{C-P}=6.9 \mathrm{~Hz}\right), 21.89,16.79\left(\mathrm{~d}, J_{C-P}=\right.$ $5.4 \mathrm{~Hz}), 16.68\left(\mathrm{~d}, J_{C-P}=5.3 \mathrm{~Hz}\right) ;{ }^{31} \mathrm{P}-\mathrm{NMR}(162 \mathrm{MHz}$, DMSO- $\left.d_{6}\right) \delta$ 20.65; Anal. Calcd. for $\mathrm{C}_{24} \mathrm{H}_{25} \mathrm{ClN}_{3} \mathrm{O}_{3}$ PS: C, 57.43; H, 5.02; N, 8.37. Found: C, 56.89; H, 5.34; N, 8.76.

\section{Diethyl((6-methyl-2-oxo-1,2-dihydroquinolin-3-yl)((5-} phenylthiazol-2-yl)amino)methyl)phosphonate (10k)

It was obtained as a white powder; yield: 90\%; m.p. $272-274{ }^{\circ} \mathrm{C} ;{ }^{1} \mathrm{H}-\mathrm{NMR} \quad\left(400 \mathrm{MHz}, \quad\right.$ DMSO- $\left.d_{6}\right) \quad \delta \quad 11.90$ $(\mathrm{s}, 1 \mathrm{H}), 8.64(\mathrm{dd}, J=9.3,3.8 \mathrm{~Hz}, 1 \mathrm{H}), 8.53(\mathrm{~s}, 1 \mathrm{H}), 8.03(\mathrm{~d}$, $J=3.5 \mathrm{~Hz}, 1 \mathrm{H}), 7.85-7.73(\mathrm{~m}, 1 \mathrm{H}), 7.68-7.58(\mathrm{~m}, 1 \mathrm{H})$, $7.57(\mathrm{~s}, 1 \mathrm{H}), 7.54-.44(\mathrm{~m}, 1 \mathrm{H}), 7.46-7.35(\mathrm{~m}, 3 \mathrm{H}), 7.27$ (ddd, $J=41.4,8.4,2.1 \mathrm{~Hz}, 3 \mathrm{H}), 6.01(\mathrm{dd}, J=20.9,9.3 \mathrm{~Hz}$, $1 \mathrm{H}), 4.23-3.90(\mathrm{~m}, 4 \mathrm{H}), 2.34(\mathrm{~s}, 3 \mathrm{H}), 1.23(\mathrm{t}, J=7.0 \mathrm{~Hz}$, 3H), $1.19-1.08$ (m, 3H); ${ }^{13} \mathrm{C}-\mathrm{NMR}$ (101 MHz, DMSO- $\left.d_{6}\right) \delta$ $166.60\left(\mathrm{~d}, J_{C-P}=10.8 \mathrm{~Hz}\right), 161.16,159.16,152.70,143.21$, $138.73,136.64,132.21,132.02,131.63,129.58,128.97$, $127.85,127.67,125.24,120.99,119.71,119.23,116.39$, $116.28,115.41,115.31,110.31,63.23\left(\mathrm{~d}, J_{C-P}=6.9 \mathrm{~Hz}\right)$, $63.04\left(\mathrm{~d}, J_{C-P}=6.9 \mathrm{~Hz}\right), 62.78,62.32,49.66,48.11,46.26$, $31.14,20.84,20.79,16.74\left(\mathrm{~d}, J_{C-P}=5.6 \mathrm{~Hz}\right), 16.59\left(\mathrm{~d}, J_{C-P}=\right.$ 5.5 Hz), 9.10: ${ }^{31} \mathrm{P}-\mathrm{NMR}\left(162 \mathrm{MHz}, \mathrm{DMSO}-d_{6}\right) \delta 19.79$; Anal. Calcd. for $\mathrm{C}_{24} \mathrm{H}_{26} \mathrm{~N}_{3} \mathrm{O}_{4} \mathrm{PS}: \mathrm{C}, 59.62 ; \mathrm{H}, 5.42 ; \mathrm{N}, 8.69$. Found: C, 59.12; H, 5.31; N, 8.17.

\section{Diethyl((6-methoxy-2-oxo-1,2-dihydroquinolin-3-yl)((5- phenylthiazol-2-yl)amino)methyl)phosphonate (10l)}

It was obtained as an orange powder; yield: 89\%; m.p. 138-139 ${ }^{\circ} \mathrm{C} ;{ }^{1} \mathrm{H}-\mathrm{NMR}\left(400 \mathrm{MHz}, \mathrm{DMSO}-d_{6}\right) \delta 11.87$ (s, $1 \mathrm{H}), 8.48(\mathrm{dd}, J=9.5,3.7 \mathrm{~Hz}, 1 \mathrm{H}), 8.09-7.92(\mathrm{~m}, 2 \mathrm{H})$, 7.94-7.76 (m, 3H), 7.67 (tdd, $J=9.9,6.2,4.2 \mathrm{~Hz}, 1 \mathrm{H})$, 7.48-7.18 (m, 7H), 7.22-7.13 (m, 1H), 7.17-7.05 (m, 3H), $7.01(\mathrm{~d}, J=13.3 \mathrm{~Hz}, 1 \mathrm{H}), 6.06(\mathrm{dd}, J=21.2,9.4 \mathrm{~Hz}, 1 \mathrm{H})$, $5.30(\mathrm{dd}, J=13.4, \quad 5.8 \mathrm{~Hz}, 1 \mathrm{H}), 4.22-4.11(\mathrm{~m}, 1 \mathrm{H})$, 4.15-4.00 (m, 2H), 3.99-3.89 (m, 1H), 3.80 (s, 3H), 1.16 $(\mathrm{dt}, J=32.3,7.0 \mathrm{~Hz}, 6 \mathrm{H}) ;{ }^{13} \mathrm{C}-\mathrm{NMR}\left(101 \mathrm{MHz}, \mathrm{DMSO}-d_{6}\right)$ $\delta 168.66,167.27\left(\mathrm{~d}, J_{C-P}=10.3 \mathrm{~Hz}\right), 160.76\left(\mathrm{~d}, J_{C-P}=\right.$ $5.3 \mathrm{~Hz}), 154.79,149.73,137.30\left(\mathrm{~d}, J_{C-P}=6.1 \mathrm{~Hz}\right), 135.11$, $133.13,130.19,128.90,128.62,127.79,127.62,126.01$ (d, $\left.J_{C-P}=2.8 \mathrm{~Hz}\right), 120.20,120.05,119.79,116.83,116.68$, $109.81,109.47,103.01,101.95,63.20\left(\mathrm{~d}, J_{C-P}=6.6 \mathrm{~Hz}\right)$, $62.98\left(\mathrm{~d}, J_{C-P}=6.9 \mathrm{~Hz}\right), 55.96,49.57,48.02,16.70\left(\mathrm{~d}, J_{C-P}=\right.$ $5.5 \mathrm{~Hz}), 16.58\left(\mathrm{~d}, J_{C-P}=5.5 \mathrm{~Hz}\right) ;{ }^{31} \mathrm{P}-\mathrm{NMR}(162 \mathrm{MHz}$, DMSO- $\left.d_{6}\right) \delta$ 21.31; Anal. Calcd. for $\mathrm{C}_{24} \mathrm{H}_{26} \mathrm{~N}_{3} \mathrm{O}_{5} \mathrm{PS}$ : C, 57.71; H, 5.25; N, 8.41. Found: C, 57.11; H, 4.89; N, 7.98.

\section{Pharmacological/biological assays}

The in vitro antimicrobial activity of all synthesized compounds was screened in terms of MIC values against six 
Gram-positive bacteria: Bacillus cereus, Staphylococcus aureus resistant to ciprofloxacin, Staphylococcus aureus ATCC 25923, Staphylococcus aureus ATCC 6538, Enterococcus faecalis ATCC 29212, Enterococcus faecalis vancomycinresistant, and 16 Gram-negative bacteria: Escherichia coli ATCC 25922, Escherichia coli ESBL (enlarged specter $\beta$-lactamase) producer, Escherichia coli ESBL producer, Escherichia coli resistant to ciprofloxacin, Klebsiella pneumoniae Carbapenem-resistant $(\mathrm{KpC}+)$, Klebsiella pneumoniae Carbapenem-sensitive (KpC-), Serratia marcescens, Salmonella typhi 14028, Pseudomonas aeruginosa ATCC 9027, Pseudomonas aeruginosa imipenem-resistant (VIM-2), Acinetobacter baumannii (NDM-1), Acinetobacter baumannii. OXA-23, Enterobacter cloacae fosfomycin resistant, Citrobacter sp, E.coli mcr-1, E.coli ATCC 8739, and fungal strains Candida albicans and Saccharomyces ceriviceae. All of them were isolated from patients hospitalized in the various departments at Annaba Hospital, Algeria. Their identification and susceptibility profile are reported by Toumi et al. [55] and Meliani et al. [56]. Four standard drugs Imipenem, Ciprofloxacin, Amikacine, and fluconazole were used as positive controls, while DMSO was used as a negative control in this study. The MIC of the compounds was determined by broth micro-dilution method and DMSO was used in $\mu \mathrm{g} / \mathrm{mL}$ [57]. The microbial suspensions were prepared in Muller-Hinton broth from test organisms sub-cultured on nutrient agar and incubated at $37^{\circ} \mathrm{C}$ for $24 \mathrm{~h}$.

Acknowledgements This study is supported by The General Directorate for Scientific Research and Technological Development (DGRSDT), Algerian Ministry of Scientific Research, Algeria. We are grateful to CRAPC SPA Expertise for recording elemental analyses and NMR spectra.

\section{Compliance with ethical standards}

Conflict of interest The authors declare no competing interests.

Publisher's note Springer Nature remains neutral with regard to jurisdictional claims in published maps and institutional affiliations.

\section{References}

1. World Health Organization. Antimicrobial resistance: global report on surveillance. World Health Organization. 2014. https://www.who.int/antimicrobial-resistance/publications/ surveillancereport/en/. Accessed 26 June 2019.

2. Centers for Disease Control and Prevention. Antibiotic resistance threats in the United States, 2019. US Department of Health and Human Services, Centers for Disease Control and Prevention. 2019. https://www.cdc.gov/drugresistance/pdf/threats-report/2019-ar-threa ts-report-508.pdf. Accessed 15 Jan 2020.

3. Akova M. Epidemiology of antimicrobial resistance in bloodstream infections. Virulence. 2016;7:252-66.

4. Blair JMA, Webber MA, Baylay AJ, Ogbolu DO, Piddock LJV. Molecular mechanisms of antibiotic resistance. Nat Rev Microbiol. 2015;13:42-51.
5. Parvaiz N, Ahmad F, Yu W, MacKerell AD Jr, Azam SS. Discovery of beta-lactamase CMY-10 inhibitors for combination therapy against multi-drug resistant Enterobacteriaceae. PLoS One. 2021;16:e244967.

6. Reddy BRP, Reddy MVK, Reddy PVG, Kumar DP, Shankar MV. Protonated trititanate nanotubes: an efficient catalyst for one-pot three-component coupling of benzothiazole amines, heterocyclic aldehydes, and dialkyl/diaryl phosphites with a greener perspective. Tetrahedron Lett. 2016;57:696-702.

7. El-Shershaby MH, El-Gamal KM, Bayoumi AH, El-Adl K, Ahmed HEA, Abulkhair HS. Synthesis, antimicrobial evaluation, DNA gyrase inhibition, and in silico pharmacokinetic studies of novel quinoline derivatives. Arch Pharm (Weinh). 2021;354:2000277.

8. Katariya KD, Shah SR, Reddy D. Anticancer, antimicrobial activities of quinoline based hydrazone analogues: synthesis, characterization and molecular docking. Bioorg Chem. 2020;94:103406.

9. Makhaeva GF, Kovaleva NV, Boltneva NP, Lushchekina SV, Astakhova TY, Rudakova EV, et al. New hybrids of 4-amino-2, 3polymethylene-quinoline and p-tolylsulfonamide as dual inhibitors of acetyl-and butyrylcholinesterase and potential multifunctional agents for Alzheimer's disease treatment. Molecules. 2020;25:3915.

10. Taha M, Sultan S, Imran S, Rahim F, Zaman K, Wadood A, et al. Synthesis of quinoline derivatives as diabetic II inhibitors and molecular docking studies. Bioorg Med Chem. 2019;27:4081-8.

11. Gao P, Wang L, Zhao L, Zhang Q, Zeng K, Zhao M, et al. Antiinflammatory quinoline alkaloids from the root bark of Dictamnus dasycarpus. Phytochemistry. 2020;172:112260.

12. Borsoi AF, Paz JD, Abbadi BL, Macchi FS, Sperotto N, Pissinate $\mathrm{K}$, et al. Design, synthesis, and evaluation of new 2-(quinoline-4yloxy) acetamide-based antituberculosis agents. Eur J Med Chem. 2020;192:112179.

13. Mohamed AH, Ramadan M. Synthesis and colon anticancer activity of some novel thiazole/-2-quinolone derivatives. J Mol Struct. 2020;1207:127798.

14. Adeleke AA, Zamisa SJ, Islam M, Olofinsan K, Salau VF, Mocktar $\mathrm{C}$, et al. Quinoline functionalized schiff base silver (I) complexes: interactions with biomolecules and in vitro cytotoxicity, antioxidant and antimicrobial activities. Molecules. 2021;26:1205.

15. Colson P, Rolain J-M, Lagier J-C, Brouqui P, Raoult D. Chloroquine and hydroxychloroquine as available weapons to fight COVID-19. Int J Antimicrob Agents. 2020;55:105932.

16. Gautret P, Lagier J-C, Parola P, Meddeb L, Mailhe M, Doudier B, et al. Hydroxychloroquine and azithromycin as a treatment of COVID-19: results of an open-label non-randomized clinical trial. Int J Antimicrob Agents. 2020;56:105949.

17. Molina JM, Delaugerre C, Goff JL, Mela-Lima B, Ponscarme D, Goldwirt L, de castro N. No evidence of rapid antiviral clearance or clinical benefit with the combination of hydroxychloroquine and azithromycin in patients with severe cOVId-19 infection. Med Mal Infect. 2020;50:384.

18. Nayak S, Gaonkar SL. A review on recent synthetic strategies and pharmacological importance of 1, 3-thiazole derivatives. Mini Rev Med Chem. 2019;19:215-38.

19. Gore VA, Tekale SU, Bhale SP, Rajani DP, Domb AJ, Pawar RP. Synthesis and biological evaluation of novel thiazole hydrazines as antimicrobial and antimalarial agents. Lett Appl Nano Biosci. 2021;10:1846-55.

20. Ghotbi G, Mahdavi M, Najafi Z, Moghadam FH, HamzehMivehroud M, Davaran S, et al. Design, synthesis, biological evaluation, and docking study of novel dual-acting thiazole-pyridiniums inhibiting acetylcholinesterase and $\beta$-amyloid aggregation for Alzheimer's disease. Bioorg Chem. 2020;103:104186.

21. Coman F-M, Mbaveng AT, Marc G, Leonte D, Brém B, Vlase L, et al. Heterocycles 47. Synthesis, characterization and biological evaluation of some new thiazole aurones as antiproliferative agents. Farmacia. 2020;68:492-506. 
22. Sundaree S, Vaddula BR, Tantak MP, Khandagale SB, Shi C, Shah K, et al. Synthesis and anticancer activity study of indolyl hydrazide-hydrazones. Med Chem Res. 2016;25:941-50.

23. Khan B, Naiyer A, Athar F, Ali S, Thakur SC. Synthesis, characterization and anti-inflammatory activity evaluation of 1,2 , 4-triazole and its derivatives as a potential scaffold for the synthesis of drugs against prostaglandin-endoperoxide synthase. J Biomol Struct Dyn. 2021;39:457-75.

24. Abdellatif RAK, Abdelgawad AM, Elshemy AH, Kahk MN, El Amir MD. Design, synthesis, antioxidant and anticancer activity of new coumarin derivatives linked with thiazole, isoxazole or pyrazole moiety. Lett Drug Des Disco. 2017;14:773-81.

25. Wang Y-X, Liu S-H, Shao Z-B, Cao L-G, Jiang K-J, Lu X, et al. Synthesis and anti-acetylcholinesterase activities of novel glycosyl coumarylthiazole derivatives. J Chem Res. 2021;45:359-64.

26. Kalkhambkar RG, Kulkarni GM, Shivkumar H, Rao RN. Synthesis of novel triheterocyclic thiazoles as anti-inflammatory and analgesic agents. Eur J Med Chem. 2007;42:1272-6.

27. KhanYusufzai S, Osman H, Khan MS, Mohamad S, Sulaiman O, Parumasivam $\mathrm{T}$, et al. Design, characterization, in vitro antibacterial, antitubercular evaluation and structure-activity relationships of new hydrazinyl thiazolyl coumarin derivatives. Med Chem Res. 2017;22:1-12.

28. Kurt BZ, Gazioglu I, Sonmez F, Kucukislamoglu M. Synthesis, antioxidant and anticholinesterase activities of novel coumarylthiazole derivatives. Bioorg Chem. 2015;59:80-90.

29. Kurt BZ, Sonmez F, Gokce B, Ergun A, Gencer N, Demir T, et al. In vitro inhibition effects on erythrocyte carbonic anhydrase I and II and structure-activity relationships of cumarylthiazole derivatives. Russ J Bioorg Chem. 2016;42:506-11.

30. Azzam MA, El-Boraey HAL, El-Sayed IET. Transition metal complexes of $\alpha$-aminophosphonates part II: Synthesis, spectroscopic characterization, and in vitro anticancer activity of copper (II) complexes of $\alpha$-aminophosphonates. Phosphorus Sulfur Silicon Relat Elem. 2020;195:339-47.

31. Maestro A, de Marigorta EM, Palacios F, Vicario J. $\alpha$-Iminophosphonates: useful intermediates for enantioselective synthesis of $\alpha$-aminophosphonates. Asian J Org Chem. 2020;9:538-48.

32. Shaikh S, Dhavan P, Pavale G, Ramana MMV, Jadhav BL. Design, synthesis and evaluation of pyrazole bearing $\alpha$-aminophosphonate derivatives as potential acetylcholinesterase inhibitors against Alzheimer's disease. Bioorg Chem. 2020;96:103589.

33. An TNM, Cuong NVan, Quang NM, Thanh TV, Alam M. Green synthesis using PEG-400 catalyst, antimicrobial activities, cytotoxicity and in silico molecular docking of new carbazole based on $\alpha$-aminophosphonate. ChemistrySelect. 2020;5:6339-49.

34. Patnala H, Abbo HS, Potla KM, Titinchi SJJ, Chinnam S. Polyethylene glycol (PEG-400): an efficient one-pot green synthesis and anti-viral activity of novel $\alpha$-diaminophosphonates. Phosphorus Sulfur Silicon Relat Elem. 2019;194:1035-9.

35. Nayab RS, Maddila S, Krishna MP, Titinchi SJJ, Thaslim BS, Chintha V, et al. In silico molecular docking and in vitro antioxidant activity studies of novel $\alpha$-aminophosphonates bearing 6-amino-1, 3-dimethyl uracil. J Recept Signal Transduct. 2020;40:166-72.

36. Akiyama T, Sanada M, Fuchibe K. Brønsted acid-mediated synthesis of $\alpha$-amino phosphonates under solvent-free conditions. Synlett. 2003;2003:1463-4.

37. Hosseini-Sarvari M. TiO2 as a new and reusable catalyst for onepot three-component syntheses of $\alpha$-aminophosphonates in solvent-free conditions. Tetrahedron. 2008;64:5459-66.

38. Kumar S, Taneja SC, Hundal MS, Kapoor KK. One-pot synthesis of $\alpha$-aminophosphonates catalyzed by antimony trichloride adsorbed on alumina. Tetrahedron Lett. 2008;49:2208-12.

39. Gallardo-Macias R, Nakayama K. Tin (II) compounds as catalysts for the Kabachnik-Fields reaction under solvent-free conditions: facile synthesis of $\alpha$-aminophosphonates. Synth (Stuttg). 2010;2010:57-62.
40. Bedolla-Medrano M, Hernández-Fernández E, Ordonez M. Phenylphosphonic acid as efficient and recyclable catalyst in the synthesis of $\alpha$-aminophosphonates under solvent-free conditions. Synlett. 2014;25:1145-9.

41. Gao G, Chen M-N, Mo L-P, Zhang Z-H. Catalyst free one-pot synthesis of $\alpha$-aminophosphonates in aqueous ethyl lactate. Phosphorus Sulfur Silicon Relat Elem. 2019;194:528-32.

42. Rasal SA, Tamore MS, Shimpi NG. Ultrasound-mediated synthesis of novel $\alpha$-aminophosphonates using graphene nanosheetssilver nanoparticles (GNS-AgNPs) as a recyclable heterogeneous catalyst. ChemistrySelect. 2019;4:2293-300.

43. Banothu J, Vaarla K, Bavantula R, Crooks PA. Sodium fluoride as an efficient catalyst for the synthesis of 2, 4-disubstituted-1, 3 -thiazoles and selenazoles at ambient temperature. Chin Chem Lett. 2014;25:172-5.

44. Meth-Cohn O. The synthesis of pyridines, quinolines and other related systems by the Vilsmeier and the reverse Vilsmeier method. Heterocycles (Senda). 1993;35:539-57.

45. Tilakraj T, Ambekar SY. Synthesis and mass spectra of some $2 \mathrm{H}-$ pyrano [2, 3-b] quinolin-2-ones. ChemInform. 1986;17.

46. Belferdi F, Merabet N, Belkhiri L, Douara B. Regioselective demethylation of quinoline derivatives. A DFT rationalization. J Mol Struct. 2016;1118:10-7.

47. Attri P, Bhatia R, Gaur J, Arora B, Gupta A, Kumar N, et al. Triethylammonium acetate ionic liquid assisted one-pot synthesis of dihydropyrimidinones and evaluation of their antioxidant and antibacterial activities. Arab J Chem. 2017;10:206-14. https://doi. org/10.1016/j.arabjc.2014.05.007.

48. Bazine I, Bendjedid S, Boukhari A. Potential antibacterial and antifungal activities of novel sulfamidophosphonate derivatives bearing the quinoline or quinolone moiety. Arch Pharm (Weinheim). 2021;354:e2000291.

49. Litim B, Cheraiet Z, Meliani S, Djahoudi A, Boukhari A. Synthesis and potent antimicrobial activity of novel coumarylthiazole $\alpha$-aminophosphonates derivatives. Mol Divers. 2021;0123456789. https://doi.org/10.1007/s11030-021-10242-2.

50. Eissa SI, Farrag AM, Abbas SY, El Shehry MF, Ragab A, Fayed EA, et al. Novel structural hybrids of quinoline and thiazole moieties: synthesis and evaluation of antibacterial and antifungal activities with molecular modeling studies. Bioorg Chem. 2021;110:104803.

51. Dorababu A. Recent update on antibacterial and antifungal activity of quinoline scaffolds. Arch Pharm (Weinh). 2021;354:2000232.

52. Karade NN, Gampawar SV, Shinde SV, Jadhav WN. L-proline catalyzed solvent-free knoevenagel condensation for the synthesis of 3-substituted coumarins. Chin J Chem. 2007;25:1686-9.

53. Ingale N, Maddi V, Palkar M, Ronad P, Mamledesai S, Vishwanathswamy AHM. et al. Synthesis and evaluation of anti-inflammatory and analgesic activity of 3-[(5-substituted-1, 3, 4-oxadiazol-2-yl-thio) acetyl]-2H-chromen-2-ones. Med Chem Res. 2012;21:16-26.

54. Zhuravel I, Kovalenko S, Vlasov S, Chernykh V. Solution-phase synthesis of a combinatorial library of 3-[4-(coumarin-3-yl)-1, 3thiazol-2-ylcarbamoyl] propanoic acid amides. Molecules. 2005; 10:444-56.

55. Toumi S, Meliani S, Amoura K, Racherache A, Djebien M, Djahoudi A. Multidrug-resistant Gram-negative bacilli producing oxacillinases and Metallo- $\beta$-lactamases isolated from patients in intensive care unit-Annaba Hospital-Algeria (2014-2016). J Appl Pharm Sci. 2018;8:107-13.

56. Meliani S, Toumi S, Djahoudi H, Deghdegh K, Amoura K, Djahoudi A. Synergistic combination of colistin with imipenem, amikacine or ciprofloxacin against Acinetobacter baumannii and Pseudomonas aeruginosa carbapenem-resistant isolated in Annaba Hospital Algeria. Biocell. 2020;44:175.

57. Guideline A. National Committee for Clinical Laboratory Standards (NCCLS) Document C38-A. NCCLS. 2002. 